\title{
Characterization of cell death caused by diplodiatoxin and dipmatol, toxic metabolites of Stenocarpella maydis
}

\author{
Mxolisi G. Masango ${ }^{\mathrm{a}, \mathrm{b},}{ }^{*}$, , Charlotte E. Ellis ${ }^{\mathrm{c}}$, Christo J. Botha ${ }^{\mathrm{b}}$ \\ ${ }^{a}$ Food, Feed and Veterinary Public Health (FFVPH), Agricultural Research Council-Onderstepoort Veterinary \\ Institute (ARC-OVI), Private Bag X05, Onderstepoort, 0110, South Africa \\ ${ }^{\mathrm{b}}$ Department of Paraclinical Sciences, Faculty of Veterinary Science, University of Pretoria, Private Bag X04, \\ Onderstepoort, 0110, South Africa \\ ${ }^{\mathrm{c}}$ Molecular Epidemiology and Diagnostics (MED), Agricultural Research Council-Onderstepoort Veterinary
Institute (ARC-OVI), Private Bag X05, Onderstepoort, 0110, South Africa
}

*Corresponding author. Agricultural Research Council-Onderstepoort Veterinary Institute (ARC-OVI), Private Bag X05,

Onderstepoort, Pretoria, 0110, South Africa.

E-mail address:

MasangoM@arc.agric.za

(M.G. Masango)

\section{Highlights}

- Diplodiatoxin and dipmatol induced necrosis in Neuro-2a, CHO-K1 and MDBK cells.

- Diplodiatoxin and dipmatol induced caspase-dependent apoptosis in vitro.

- Mitochondrial damage, cytoplasmic vacuoles and nuclear fragmentation were observed.

\begin{abstract}
Diplodiosis, a neuromycotoxicosis of cattle and sheep grazing on mouldy cobs infected by Stenocarpella maydis, is considered the last major veterinary mycotoxicosis for which the causative mycotoxin is still unknown. The current study was aimed at characterizing the cell death observed in mouse neuroblastoma (Neuro-2a), Chinese hamster ovary (CHO-K1) and Madin-Darby bovine kidney (MDBK) cell lines exposed to the $S$. maydis metabolites (i.e. diplodiatoxin and dipmatol) by investigating the roles of necrosis and apoptosis. Necrosis was investigated using the lactate dehydrogenase (LDH) leakage and propidium iodide (PI) flow cytometry assays and apoptosis was evaluated using the caspase-3/7 and Annexin V flow cytometry assays. In addition, transmission electron microscopy (TEM) was used to correlate the cell death pathways observed in this study with their typical morphologies. Both diplodiatoxin and dipmatol $(750 \mu \mathrm{M})$ induced necrosis and caspase-dependent apoptosis in Neuro-2a, CHO-K1 and MDBK cells. Ultrastructurally, the two mycotoxins induced mitochondrial damage, cytoplasmic vacuolation and nuclear fragmentation in the three cell lines. These findings have laid a foundation for future studies aimed at elucidating in detail the mechanism of action of the S. maydis metabolites.
\end{abstract}

Keywords: Stenocarpella maydis; Diplodiosis; Diplodiatoxin; Dipmatol; Necrosis; Apoptosis 


\section{Introduction}

Maize (Zea mays L.) is produced worldwide and is cultivated in more regions than any other crop. It is regarded as the most important grain crop in South Africa since it is the major feed grain and staple food for the majority of the South African population ( DAFF, 2013).

Stenocarpella maydis (Berk.) Sutton (previously named Diplodia maydis (Berk.) Sacc.) is one of the most prevalent ear and stalk rot pathogens of maize globally, causing reductions in grain quality and yield, as well as lodging of plants with infected ears and stalks ( Flett and McLaren, 1994). S. maydis is known to cause diplodiosis, a neuromycotoxicosis of cattle and sheep grazing on mouldy cobs infected with S. maydis ( Riet-Correa et al., 2013). Although this disease is most common in southern Africa (Masango et al., 2015), it has also been reported in Australia (Darvall, 1964), Argentina (Odriozola et al., 2005) and Brazil (RietCorrea et al., 2013). Diplodiosis is considered the last major veterinary mycotoxicosis for which the causative mycotoxin is still unknown (Marasas et al., 2012).

Since the first description of diplodiosis in 1914 by Van der Bilj (1914), efforts have been made to isolate the principal toxin(s) responsible for this mycotoxicosis. To date, different metabolites (i.e. diplodiatoxin, dipmatol, chaetoglobosins and diplonine) have been isolated from S. maydis-contaminated cultures ( Ackerman et al., 1995, Rogers et al., 2014, Snyman et al., 2011 and Steyn et al., 1972). A major drawback is that none of these S. maydis metabolites isolated thus far have been administered to ruminants in an attempt to reproduce diplodiosis. Therefore, the specific role which these metabolites play in diplodiosis has not yet been established ( Masango et al., 2015).

To circumvent animal ethical issues in vitro assays are utilized and these play a critical role in enhancing our understanding of the harmful effects caused by toxins/chemicals in animals and humans (Freshney, 2001). In an attempt to elucidate the mechanisms of action of the currently known metabolites purified from South African fungal isolates (i.e. diplodiatoxin, dipmatol and diplonine), we recently evaluated the cytotoxicity of the $S$. maydis metabolites using cell cultures (mouse neuroblastoma [Neuro-2a], Chinese hamster ovarian [CHO-K1] and Madin-Darby bovine kidney [MDBK] cell lines) ( Masango et al., 2014). The results obtained indicated that diplodiatoxin (effective concentration at $50 \%\left[\mathrm{EC}_{50}\right]=147 \mu \mathrm{M}$ ) and dipmatol $\left(\mathrm{EC}_{50}=686 \mu \mathrm{M}\right)$ were cytotoxic, with the lowest $\mathrm{EC}_{50}$ values recorded on MDBK cells at $72 \mathrm{~h}$ post exposure. Diplonine was not cytotoxic to the three cell lines tested at comparable concentrations.

To better understand the cell death observed in the three cell lines exposed to the $S$. maydis metabolites, the roles of necrosis and apoptosis were investigated. Necrosis was investigated using the lactate dehydrogenase (LDH) leakage and propidium iodide (PI) staining assays, and apoptosis was evaluated using the caspase-3/7 and Annexin V flow cytometry assays. Lastly, transmission electron microscopy (TEM) was used to correlate the cell death pathways with their typical morphologies.

\section{Materials and methods}

\subsection{Chemicals and reagents}

All the chemicals and reagents were purchased from Sigma Aldrich (South Africa) unless otherwise stated. Cell culture plates and flasks were purchased from Lasec (South Africa). 


\subsection{Stenocarpella maydis metabolites}

Diplodiatoxin (Steyn et al., 1972) and dipmatol (Ackerman et al., 1995) were utilized. The stock solutions of the toxic metabolites were prepared in DMSO. The working solutions of the toxins were prepared in the corresponding cell culture media.

\subsection{Cell cultures}

The Neuro-2a, CHO-K1 and MDBK cells were obtained from the American Type Culture Collection (ATCC, USA). The cells were grown in DMEM (Dulbecco's modified Eagle's medium) (Neuro-2a cells) or DMEM and Ham's F-12 Nutrient Mixture (CHO-K1 and MDBK cells) supplemented with $10 \%$ foetal calf serum, $100 \mathrm{U} / \mathrm{ml}$ penicillin, $100 \mu \mathrm{g} / \mathrm{ml}$ streptomycin and $2.5 \mu \mathrm{g} / \mathrm{ml}$ amphotericin B (Fungizone) in a humidified atmosphere of $5 \%$ $\mathrm{CO}_{2}$ at $37^{\circ} \mathrm{C}$. The cells were cultured in $75 \mathrm{~cm}^{2}$ cell culture flasks.

\subsection{Exposure of cell cultures to Stenocarpella maydis metabolites}

The cell cultures were seeded in 24 -well plates at a density of $1 \times 10^{6}$ cells $/ \mathrm{ml}$. After attaching to the wells ( $24 \mathrm{~h}$ post-seeding), cells were exposed to $500 \mu \mathrm{l}$ of diplodiatoxin and dipmatol at concentrations of 100,350 and $750 \mu \mathrm{M}$ for 24,48 and $72 \mathrm{~h}$. Control wells contained cells and $500 \mu \mathrm{l}$ of the corresponding culture medium only.

\subsection{Necrosis assays}

\subsubsection{Lactate dehydrogenase (LDH) assay}

Plasma membrane integrity was evaluated by measuring the LDH activity using the CytoToxONE $^{\text {TM }}$ homogeneous membrane integrity assay kit (Promega, USA). The LDH released into the culture medium, following treatment of the cells with the $S$. maydis toxins, was measured with an enzymatic reaction that involves the conversion of resazurin into resorufin (Promega Technical Bulletin). At the end of the exposure period, $100 \mu \mathrm{l}$ of the cell culture medium was removed from each experimental well and transferred into a 96-well opaque-walled tissue culture plate. An equal volume $(100 \mu \mathrm{l})$ of the CytoTox-ONETM reagent was added to $100 \mu \mathrm{l}$ medium-containing wells and the plate was incubated overnight at room temperature. At the end of the incubation, $50 \mu \mathrm{l}$ of stop solution was added to each well and the fluorescence was measured using the Fluoroskan Ascent FL reader (Thermo Electron Corporation, USA) at $560 \mathrm{~nm}$ excitation and $590 \mathrm{~nm}$ emission wavelengths. Results were analyzed using the GraphPad Prism software (version 4.0) package. LDH release was estimated as the percentage absorbance of each sample relative to the controls. Three independent experiments were carried out with two replicate wells for each toxin concentration.

\subsubsection{Propidium iodide (PI) flow cytometry assay}

In addition, propidium iodide (PI) was used to stain cells with damaged plasma membranes. At the end of the exposure period, cells were trypsinized by adding $500 \mu \mathrm{l}$ trypsin-versene EDTA to each well. Cells were transferred to sterile $2 \mathrm{ml}$ Eppendorf tubes and $1 \mathrm{ml}$ Dulbecco's PBS (DPBS) was added to each tube. Tubes containing trypsinized cells were centrifuged at $3000 \mathrm{rpm}$ for $3 \mathrm{~min}$ and the supernatant was carefully discarded. The pellets were then resuspended in $1 \mathrm{ml}$ DPBS and centrifuged as before. Cells were resuspended by adding $1 \mathrm{ml}$ of the binding buffer to each tube. Five hundred microlitres of cell suspension 
was transferred to sterile $2 \mathrm{ml}$ Eppendorf tubes. Ten microlitres of PI solution was added to each cell suspension and tubes were incubated for $10 \mathrm{~min}$ at room temperature while being protected from light. Fluorescence was measured immediately (i.e. 10,000 events were captured per sample) using the Cytomics FC 500 flow cytometer (Beckman Coulter, USA) and analyzed with the Kaluza 1.1 software package. Results were analyzed using the GraphPad Prism software (version 4.0) package. The PI uptake was estimated as the percentage fluorescence of each sample relative to the controls. Two independent experiments were carried out for each toxin concentration.

\subsection{Apoptosis assays}

\subsubsection{Caspase- $3 / 7$ assay}

Apoptosis was evaluated by measuring the activity of the caspase-3/7 enzymes using the APO-ONE ${ }^{\circledR}$ homogeneous caspase-3/7 assay kit (Promega, USA). At the end of the exposure period, $100 \mu \mathrm{l}$ of the cell culture medium was removed from each experimental well and transferred to wells in a 96-well opaque-walled tissue culture plate. An equal volume $(100 \mu \mathrm{l})$ of the APO-ONE ${ }^{\circledR}$ reagent was added to $100 \mu 1$ medium-containing wells and the plate was incubated for $1 \mathrm{~h}$ at room temperature. At the end of the incubation, fluorescence was measured using the Fluoroskan Ascent FL reader (Thermo Electron Corporation, USA) at $485 \mathrm{~nm}$ excitation and $530 \mathrm{~nm}$ emission wavelengths. Results were analyzed using the GraphPad Prism software (version 4.0) package. The caspase-3/7 activity was estimated as the percentage fluorescence of each sample relative to the controls. Three independent experiments were carried out with two replicate wells for each toxin concentration.

\subsubsection{Annexin V flow cytometry assay}

The Annexin V-fluorescein isothiocyanate (FITC) apoptosis detection kit (Sigma Aldrich) was also used to detect apoptotic cells. At the end of the exposure period, cells were trypsinized with trypsin-versene EDTA, washed with DPBS, and centrifuged as described for the PI assay and resuspended in the binding buffer. Five hundred microlitres of cell suspension was transferred to sterile $2 \mathrm{ml}$ Eppendorf tubes. Five microlitres of Annexin V solution was added to each cell suspension and tubes were incubated for $10 \mathrm{~min}$ at room temperature while being protected from light. Fluorescence was measured immediately (i.e. 10,000 events were captured per sample) using the Cytomics FC 500 flow cytometer (Beckman Coulter, USA) and analyzed using the Kaluza 1.1 software package. Results were analyzed using the GraphPad Prism software (version 4.0) package. The induction of apoptosis (Annexin V activity) was estimated as the percentage fluorescence of each sample relative to the controls. Two independent experiments were carried out for each toxin concentration.

\subsection{Transmission electron microscopy (TEM)}

Subcellular changes typical of apoptosis and necrosis were investigated for the three cell lines after exposure to $750 \mu \mathrm{M}$ of diplodiatoxin and dipmatol for 24,48 and $72 \mathrm{~h}$ using TEM based on the modified method of Glauert (1980). For comparison purposes, staurosporine $(1 \mu \mathrm{M})$ and Triton-X $(0.01 \%)$ were used as positive inducers of apoptosis (Zhang et al., 1998) and necrosis (Weyermann et al., 2005), respectively. Cells exposed to media only were used as controls. At the end of the exposure period, cells were fixed in $2.5 \%$ glutaraldehyde in Millonig's buffer for 5 min before detachment using a cell scraper. Loose cells were 
transferred to $2 \mathrm{ml}$ Eppendorf tubes and pelleted using centrifugation at $3000 \mathrm{rpm}$ for $3 \mathrm{~min}$. Pellets were resuspended in Millonig's buffer and fixed for an hour. The cells were further fixed in $1 \%$ osmium tetroxide in Millonig's buffer, followed by washing and dehydration in buffer and graded alcohols. Cells were then embedded in absolute resin at $60{ }^{\circ} \mathrm{C}$. The cells were pelleted after each step using centrifugation at $3000 \mathrm{rpm}$ for $3 \mathrm{~min}$. Following overnight curing, ultra-thin sections were prepared and stained with lead citrate and uranyl acetate. The prepared sections were viewed using a Phillips CM10 transmission electron microscope operated at $80 \mathrm{kV}$.

\subsection{Statistical analysis}

A factorial analysis of variance (ANOVA) was used for analysis of the LDH, PI flow cytometry, caspase-3/7 and Annexin V flow cytometry datasets which included the toxins (diplodiatoxin and dipmatol) and cell types (Neuro-2a, CHO-K1 and MDBK). Standardized values for all datasets were tested for normality deviations using the Shapiro-Wilk's test. Pearson's correlation $(r)$ was used to determine the linear correlation between different parameters of the LDH and PI flow cytometry, and caspase-3/7 and Annexin V flow cytometry assays. Correlation was considered significant when $P \leq 0.0001$ (SAS/STAT version 9.2). All results were presented as percentages (mean \pm SEM) compared to the controls, with $P$ values $<0.05$ considered statistically significant.

\section{Results}

\subsection{Necrosis analysis}

A significant difference $(P<0.05)$ in LDH leakage was observed following treatment of the three cell lines with $750 \mu \mathrm{M}$ of diplodiatoxin ( Fig. 1). The amount of LDH released at this concentration ranged from $236 \pm 10 \%-260 \pm 7 \%$ for Neuro-2a, $109 \pm 1 \%-155 \pm 8 \%$ for CHO-K1 and $125 \pm 16 \%-195 \pm 12 \%$ for MDBK cells. A concentration-dependent release of LDH was observed following exposure of the Neuro-2a cells to dipmatol, with the highest LDH release $(188 \pm 5 \%-259 \pm 7 \%)$ being recorded at $750 \mu \mathrm{M}$ toxin concentration (Fig. 1). There was a significant difference $(P<0.05)$ in LDH leakage after treatment of CHO-K1 $(118 \pm 2 \%-174 \pm 5 \%)$ and MDBK $(165 \pm 6 \%-194 \pm 14 \%)$ cells with the highest concentration $(750 \mu \mathrm{M})$ of dipmatol. 

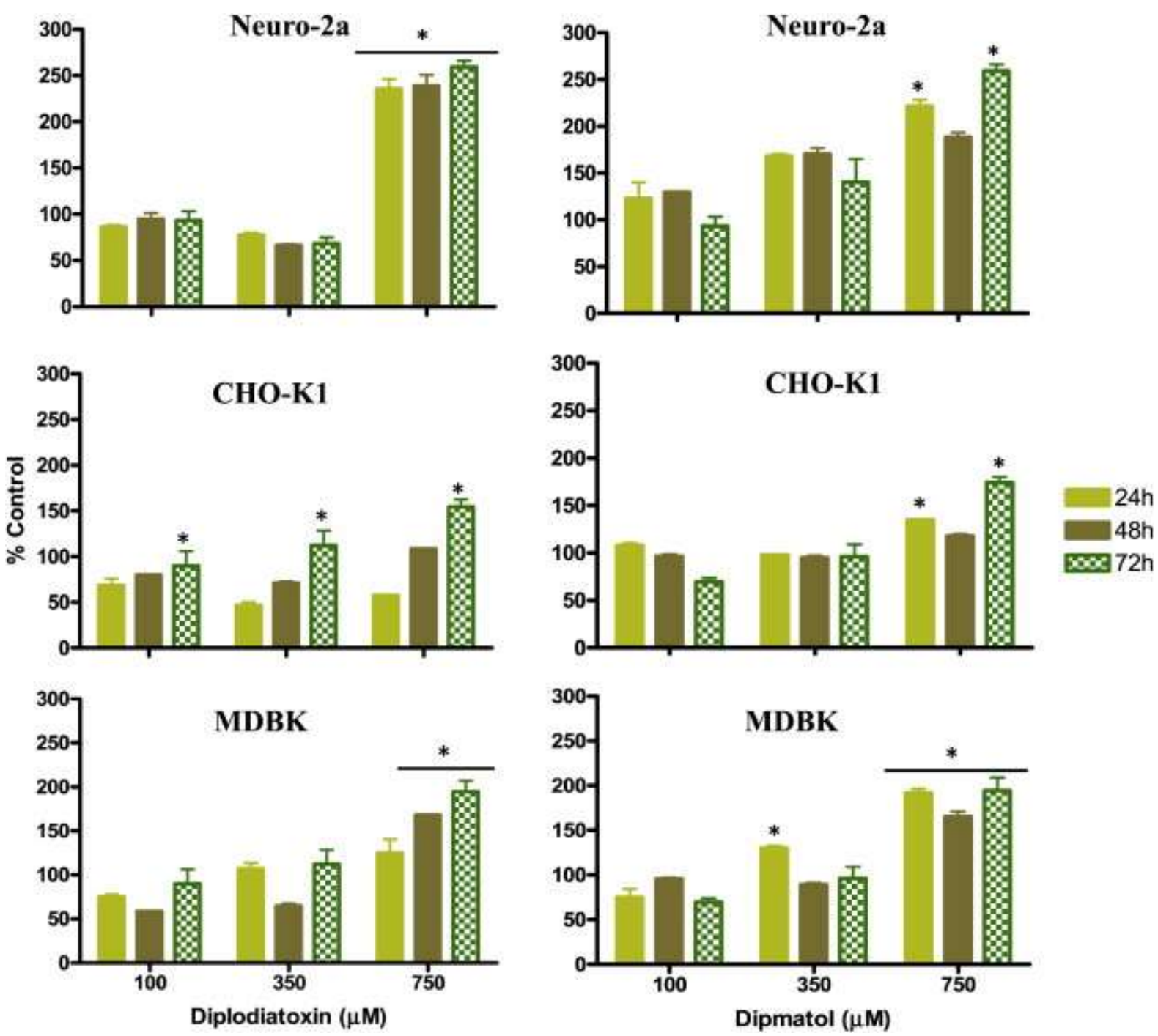

Fig. 1. Lactate dehydrogenase (LDH) enzyme leakage following exposure of Neuro-2a, CHO-K1 and MDBK cells to diplodiatoxin and dipmatol for 24,48 and $72 \mathrm{~h}$. Results are presented as percentage leakage (mean \pm SEM) compared to the controls $(* P<0.05)$.

Cells with damaged plasma membranes following exposure to the $S$. maydis toxins were also detected by their ability to absorb the PI dye which was intercalated into their nuclei. The highest PI uptake was recorded following treatment of Neuro-2a (174 $\pm 24 \%-299 \pm 28 \%)$, CHO-K1 $(155 \pm 2 \%-242 \pm 5 \%)$ and MDBK $(151 \pm 12 \%-202 \pm 19 \%)$ cells with $750 \mu \mathrm{M}$ of diplodiatoxin ( Fig. 2). Treatment with $750 \mu \mathrm{M}$ dipmatol induced the highest PI uptake in Neuro-2a (103 $\pm 32 \%-205 \pm 45 \%)$ and CHO-K1 (134 $\pm 2 \%-163 \pm 1 \%)$ cells (Fig. 2). The highest PI uptake recorded for MDBK cells $(142 \pm 10 \%)$ was for the $24 \mathrm{~h}$ exposure period at the highest dipmatol concentration (Fig. 2). 

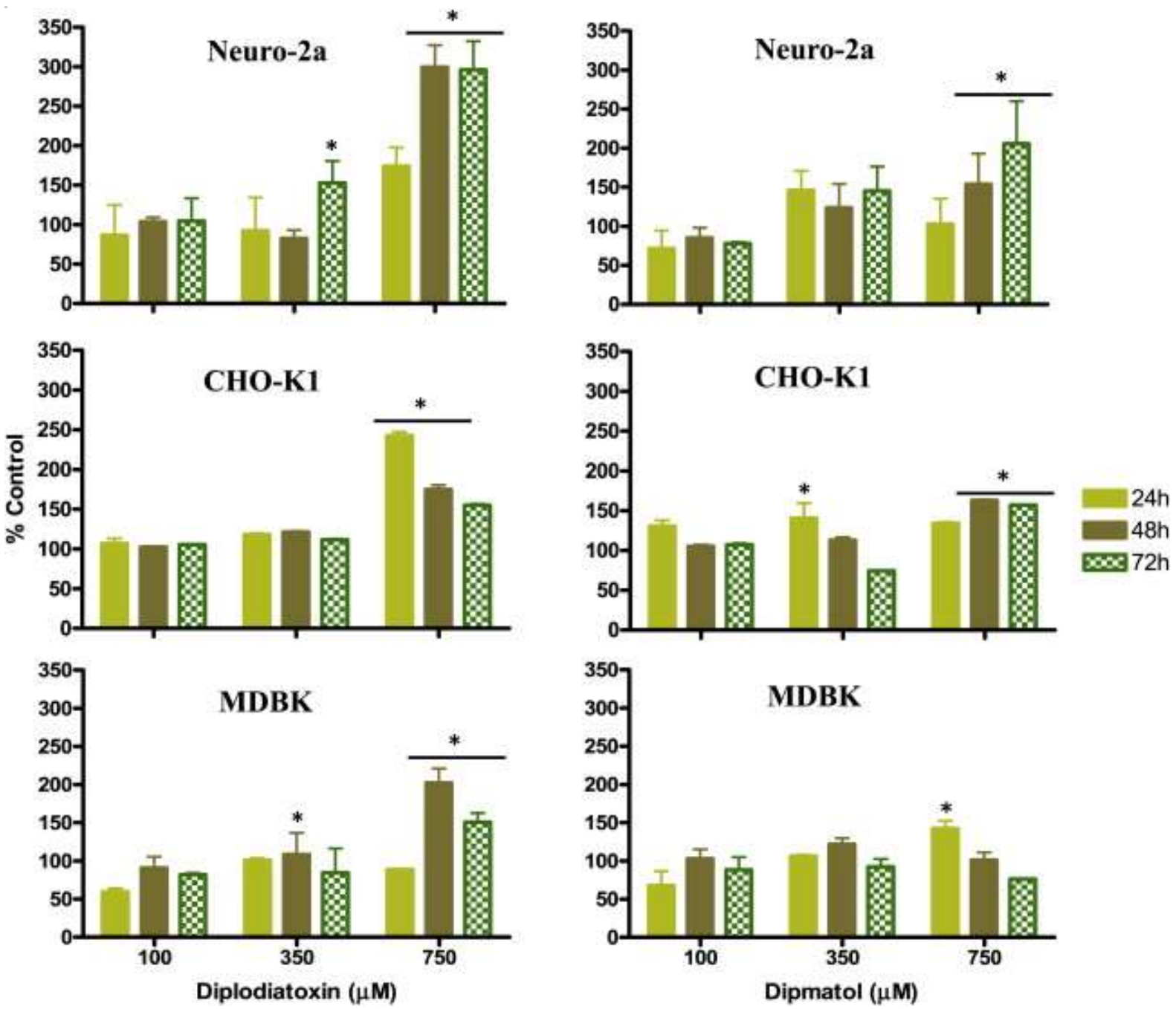

Fig. 2. Propidium iodide (PI) uptake (flow cytometry) following exposure of Neuro-2a, CHO-K1 and MDBK cells to diplodiatoxin and dipmatol for 24,48 and $72 \mathrm{~h}$. Results are presented as percentage uptake (mean \pm SEM) compared to the controls $(* P<0.05)$.

\subsection{Apoptosis analysis}

Apoptotic cells were detected after exposure to diplodiatoxin and dipmatol at 100, 350 and $750 \mu \mathrm{M}$ concentrations using the caspase- $3 / 7$ and Annexin V flow cytometry assays. High caspase activities were recorded for Neuro- $2 \mathrm{a}(148 \pm 47 \%-376 \pm 46 \%$ at $350 \mu \mathrm{M}$ and $149 \pm 14 \%-597 \pm 69 \%$ at $750 \mu \mathrm{M})$ and $\operatorname{MDBK}(376 \pm 44 \%-509 \pm 75 \%$ at $350 \mu \mathrm{M})$ cells after exposure to diplodiatoxin (Fig. 3). The caspase activity induced in CHO-K1 cells (e.g. $156 \pm 19 \%$ at $350 \mu \mathrm{M}$ after $48 \mathrm{~h}$ ) exposed to diplodiatoxin was the lowest and significantly different $(P<0.05)$ when compared to those of Neuro-2a and MDBK cells ( Fig. 3). A concentration-dependent increase in the caspase-3/7 activity was recorded after exposure of Neuro-2a and CHO-K1 cell cultures to dipmatol (Fig. 3). The highest enzyme activity was measured in Neuro-2a $(172 \pm 17 \%-273 \pm 44 \%)$ and CHO-K1 $(134 \pm 11 \%-249 \pm 43 \%)$ cells exposed to $750 \mu \mathrm{M}$ dipmatol. The caspase activity induced following a $48 \mathrm{~h}$ exposure period of MDBK cells to dipmatol was the highest $(430 \pm 75 \%$ at $350 \mu \mathrm{M})$ and significantly different $(P<0.05)$ compared to Neuro-2a and CHO-K1 cells ( Fig. 3). 

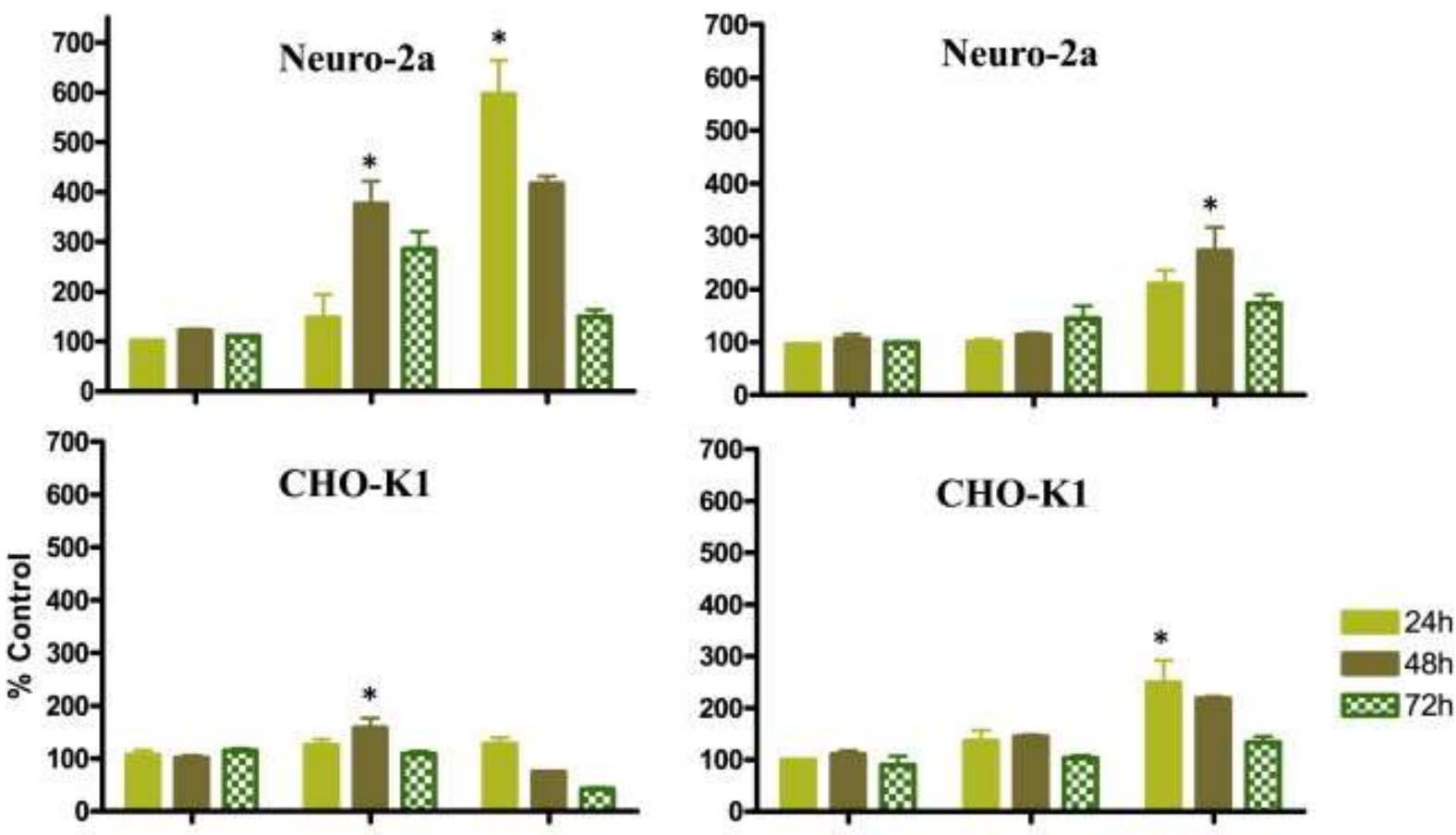

$\cos 72 \mathrm{~h}$
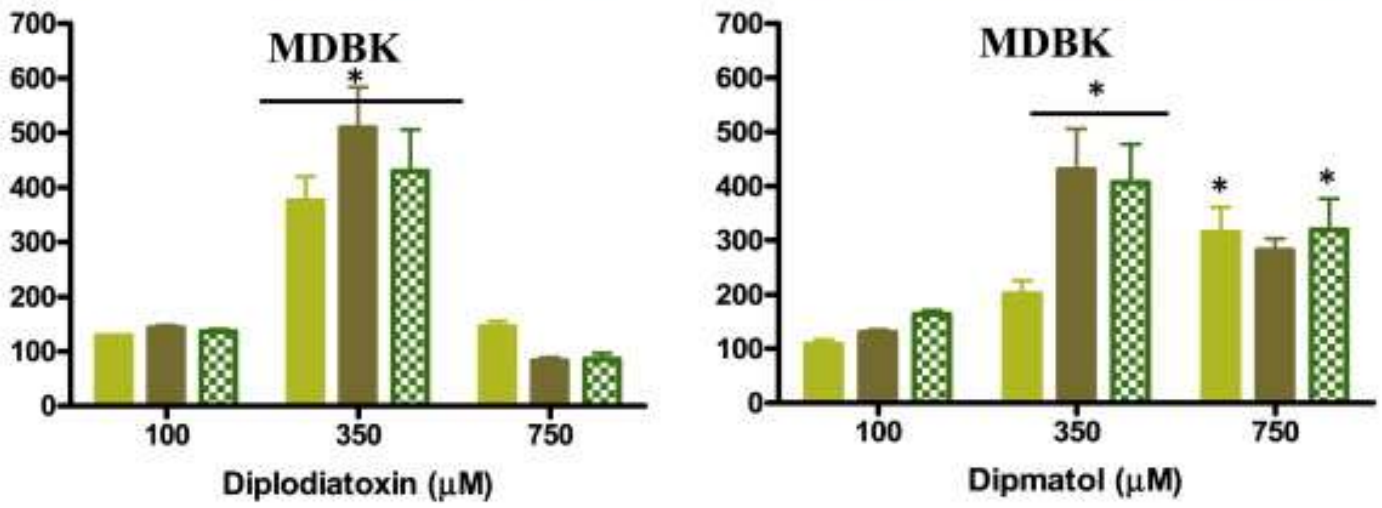

Fig. 3. Caspase-3/7 enzyme activity following exposure of Neuro-2a, CHO-K1 and MDBK cells to diplodiatoxin and dipmatol for 24,48 and $72 \mathrm{~h}$. Results are presented as percentage activity (mean \pm SEM) compared to the controls $(* P<0.05)$.

The presence of apoptotic cells following exposure to diplodiatoxin and dipmatol was confirmed using the Annexin V flow cytometry assay. A concentration-dependent increase in the Annexin $\mathrm{V}$ binding activity was measured after exposure of the three cell lines to diplodiatoxin (Fig. 4), with high enzyme activities recorded in Neuro-2a (163 $\pm 14 \%-$ $265 \pm 31 \%)$, CHO-K1 $(160 \pm 7 \%-170 \pm 1 \%)$ and MDBK $(109 \pm 19 \%-176 \pm 11 \%)$ cells treated with the highest toxin concentrations $(750 \mu \mathrm{M})$. High Annexin V binding activities were recorded in Neuro-2a cells $(239 \pm 5 \%-348 \pm 11 \%$ at $350 \mu \mathrm{M}$ and $148 \pm 3 \%-268 \pm 16 \%$ at $750 \mu \mathrm{M}$, respectively) exposed to dipmatol (Fig. 4). Annexin V activities measured in the CHO-K1 $(133 \pm 9 \%)$ and MDBK $(123 \pm 15 \%)$ cells after exposure to $750 \mu \mathrm{M}$ dipmatol were lower when compared to those of the Neuro-2a cells (Fig. 4). 

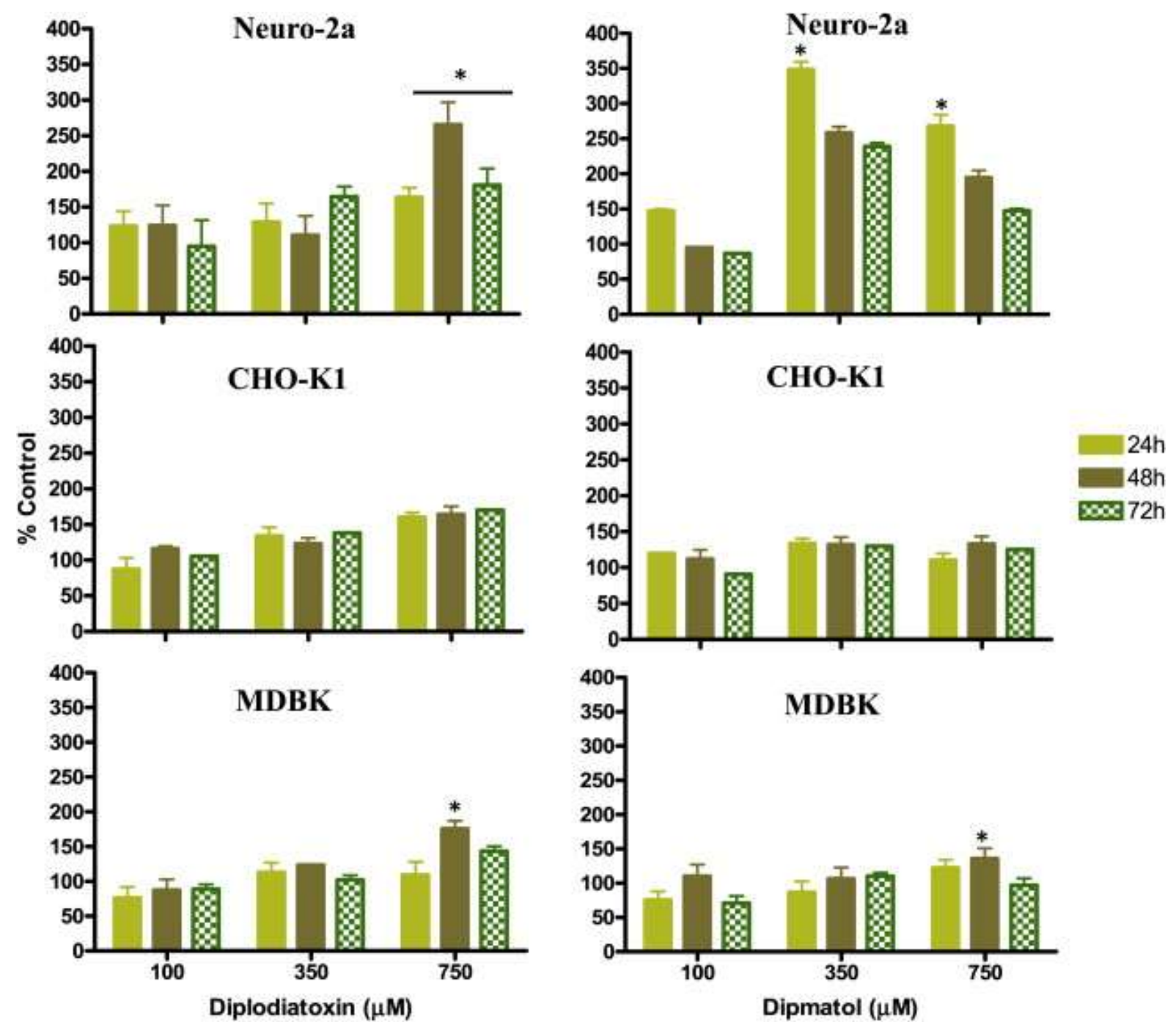

Fig. 4. Annexin V activity (flow cytometry) following exposure of Neuro-2a, CHO-K1 and MDBK cells to diplodiatoxin and dipmatol for 24,48 and $72 \mathrm{~h}$. Results are presented as percentage activity (mean \pm SEM) compared to the controls $(* P<0.05)$.

\subsection{Ultrastructural features}

The subcellular changes observed in Neuro-2a cells following treatment for 24, 48 and $72 \mathrm{~h}$ with diplodiatoxin and dipmatol are shown in Fig. 5. Numerous vacuoles and granules were visible in the cytoplasm of the cells after exposure for $24 \mathrm{~h}$ to diplodiatoxin (Fig. 5A). Mitochondria were not visible in the cytoplasm at $24 \mathrm{~h}$ when compared with the control Neuro-2a cells (Fig. S1A). At this stage of exposure, the nuclear and plasma membranes were intact. The most notable changes at $48 \mathrm{~h}$ of exposure to diplodiatoxin included the absence of nuclei and mitochondria as well as the presence of numerous electron-lucent vacuoles (Fig. 5B). A large number of electron-dense granules/structures were seen in the cytoplasm. The plasma membrane was still intact after $48 \mathrm{~h}$ of exposure to diplodiatoxin. Complete disruption of the cells, accompanied by the loss of plasma membrane, was evident after $72 \mathrm{~h}$ of exposure of Neuro-2a cells to diplodiatoxin (Fig. 5C) and these changes were similar to those of the necrotic Neuro-2a cells (Fig. S1I). 

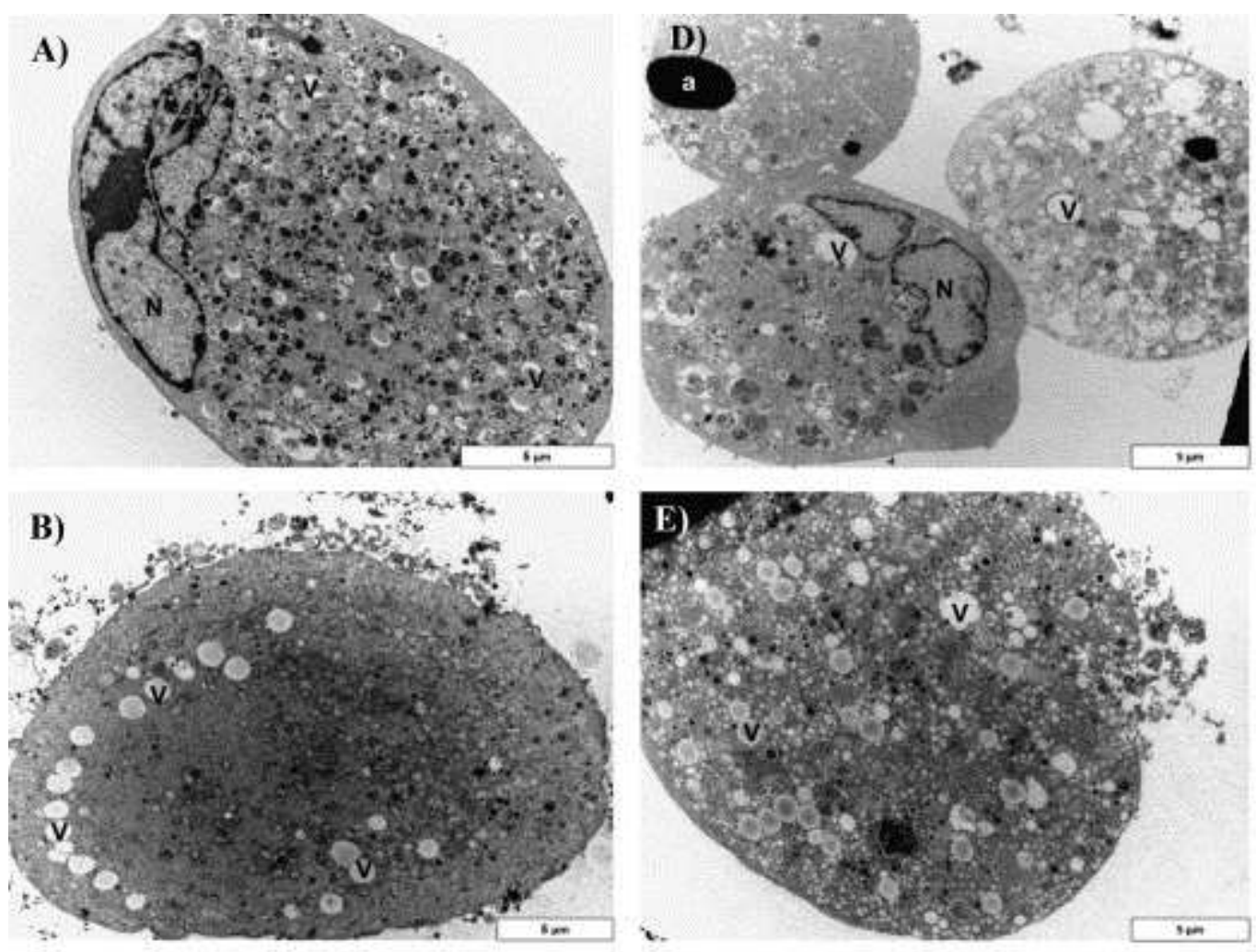

$24 h$

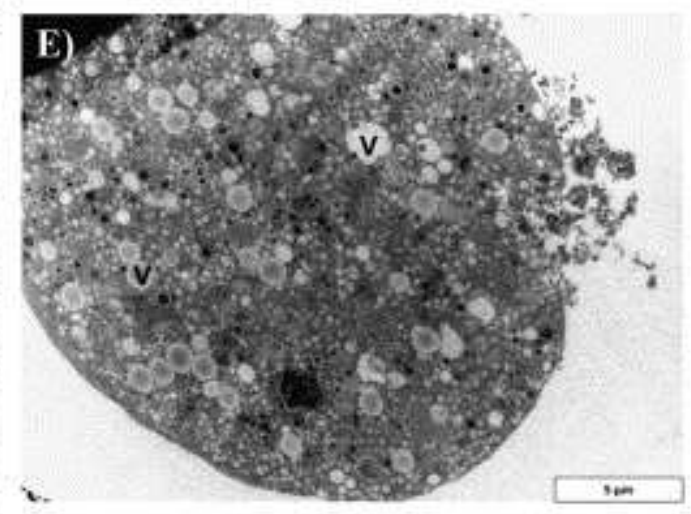

$48 \mathrm{~h}$
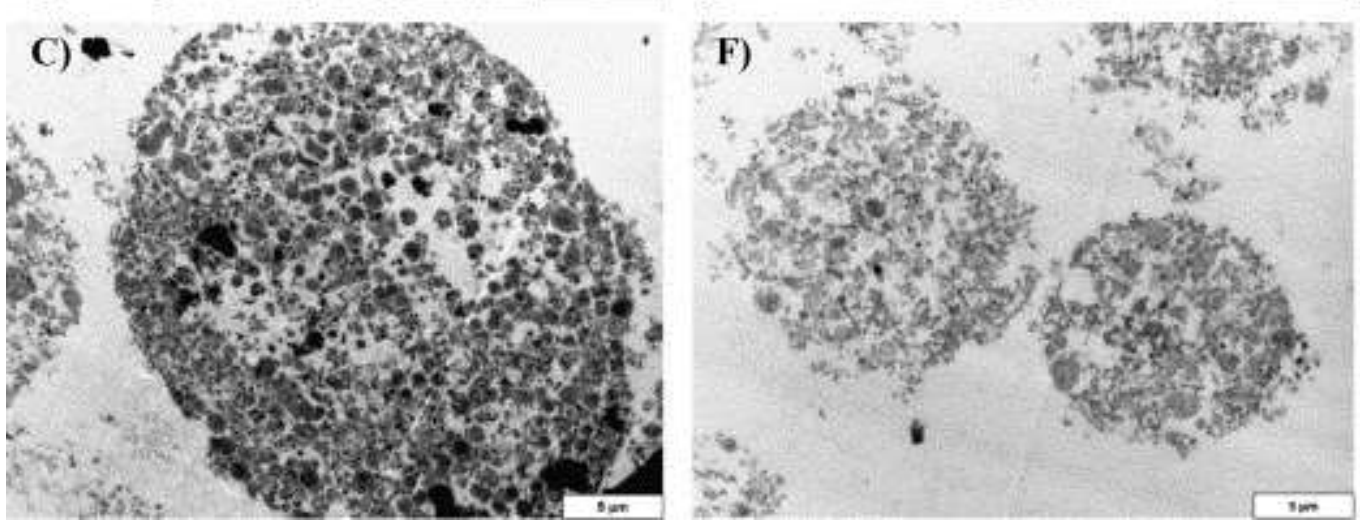

$72 \mathrm{~h}$

Fig. 5. Electron micrographs showing Neuro-2a cells exposed to $750 \mu \mathrm{M}$ of diplodiatoxin (A, B, C) and dipmatol (D, E, F) for 24, 48 and $72 \mathrm{~h}$. $\mathrm{N}$ = nucleus; $\mathrm{V}=$ vacuoles; $\mathrm{a}=$ staining artefact.

The Neuro-2a cultures treated with dipmatol for $24 \mathrm{~h}$ contained numerous vacuoles and electron-dense round structures in the cytoplasm (Fig. 5D) which were similar to those observed in the apoptotic Neuro-2a cells (Fig. S1D). The plasma membrane appeared to be intact at this stage. A large number of vacuoles (electron-dense and -lucent) were visible in the cytoplasm at $48 \mathrm{~h}$ of exposure to dipmatol (Fig. 5E). Complete disappearance of nuclei and mitochondria was evident. At $72 \mathrm{~h}$, complete disruption of the Neuro-2a cells was observed (Fig. 5F) and the changes were similar to those observed in the necrotic Neuro-2a cells (Fig. S1I).

Fig. 6 depicts the subcellular changes observed in CHO-K1 cells following treatment with diplodiatoxin and dipmatol for 24, 48 and $72 \mathrm{~h}$. The most noticeable changes in CHO-K1 cells exposed to diplodiatoxin included the complete disappearance of mitochondria and the fragmentation of nuclei and cytoplasm (Fig. 6A-C) when compared with the control CHO$\mathrm{K} 1$ cells (Fig. S2A-C). The nuclear and plasma membranes appeared to be intact after $24 \mathrm{~h}$ of exposure to diplodiatoxin (Fig. 6A). Disruption of the cytoplasm intensified with prolonged 
exposure to the toxin (Fig. 6B and $\mathrm{C}$ ) and these changes were similar to those observed in the necrotic CHO-K1 cells (Fig. S2G and SH). The plasma membranes of some of the cells still appeared to be intact after 48 and $72 \mathrm{~h}$ exposure (Fig. 6B and C), however, partial disruption of the plasma membranes was evident and consistent with the necrotic CHO-K1 cells (Fig. S2H and SI).
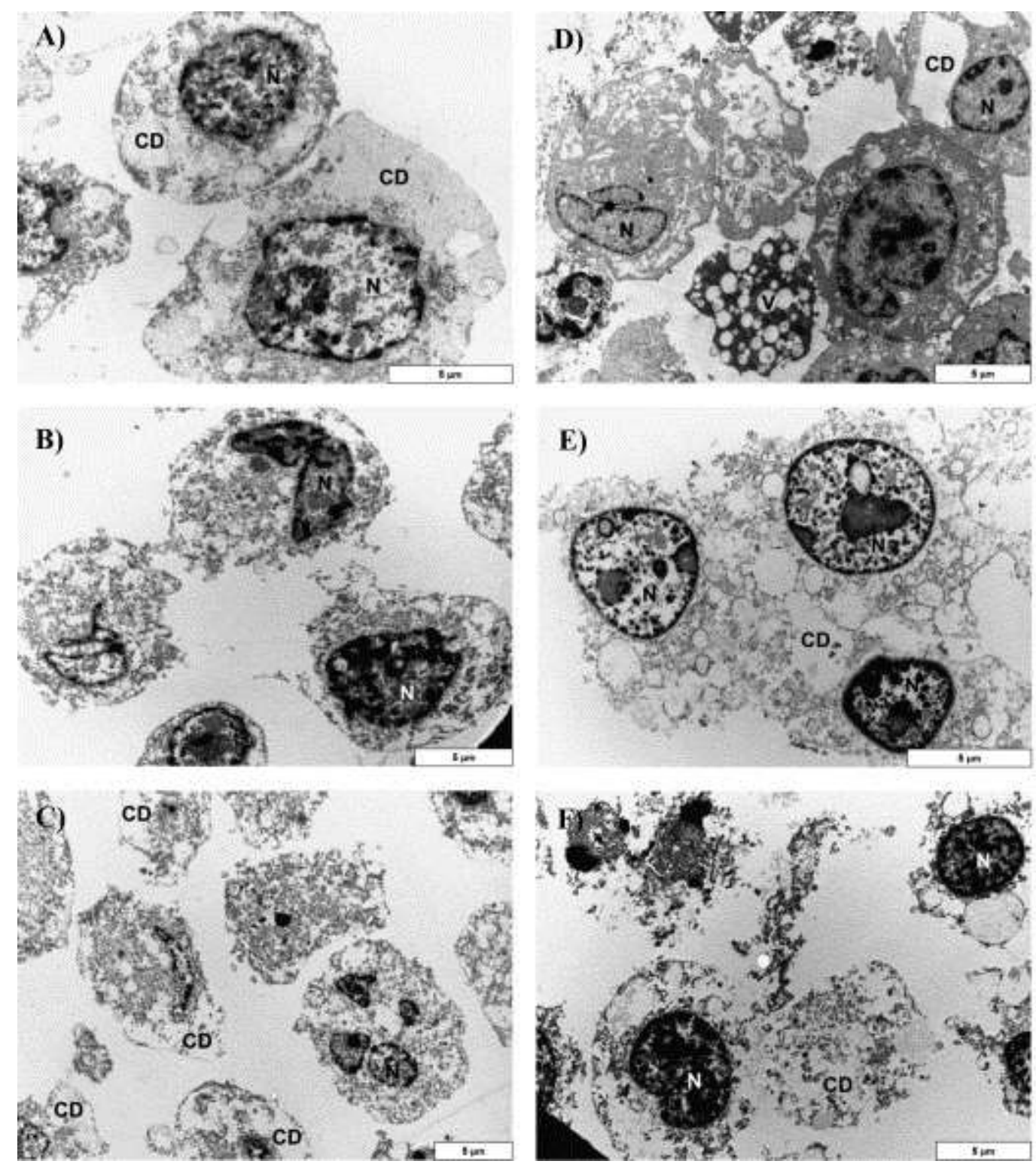

$72 \mathrm{~h}$

Fig. 6. Electron micrographs showing $\mathrm{CHO}-\mathrm{K} 1$ cells exposed to $750 \mu \mathrm{M}$ of diplodiatoxin (A, B, C) and dipmatol (D, E, F) for 24, 48 and $72 \mathrm{~h}$. $\mathrm{N}=$ nucleus; $\mathrm{V}=$ vacuoles; $\mathrm{CD}=$ cytoplasmic disruption.

The CHO-K1 cultures exposed for $24 \mathrm{~h}$ to dipmatol contained numerous electron-lucent vacuoles which had progressed to complete disruption of the cytoplasm in some instances (Fig. 6D) when compared with the control CHO-K1 cells (Fig. S2A). At this stage, there was complete disappearance of the mitochondria and the majority of nuclear and plasma membranes appeared to be intact. Complete disruption of the cytoplasm and plasma membranes was observed with prolonged exposure (Fig. 6E and F) and these changes were similar to those observed with the necrotic CHO-K1 cells (Fig. S2H and SI). The nuclear membrane appeared to have been intact in most of the CHO-K1 cells exposed to dipmatol at 48 and $72 \mathrm{~h}$, however, fragmentation of the nuclear matrix was evident in these cells. 

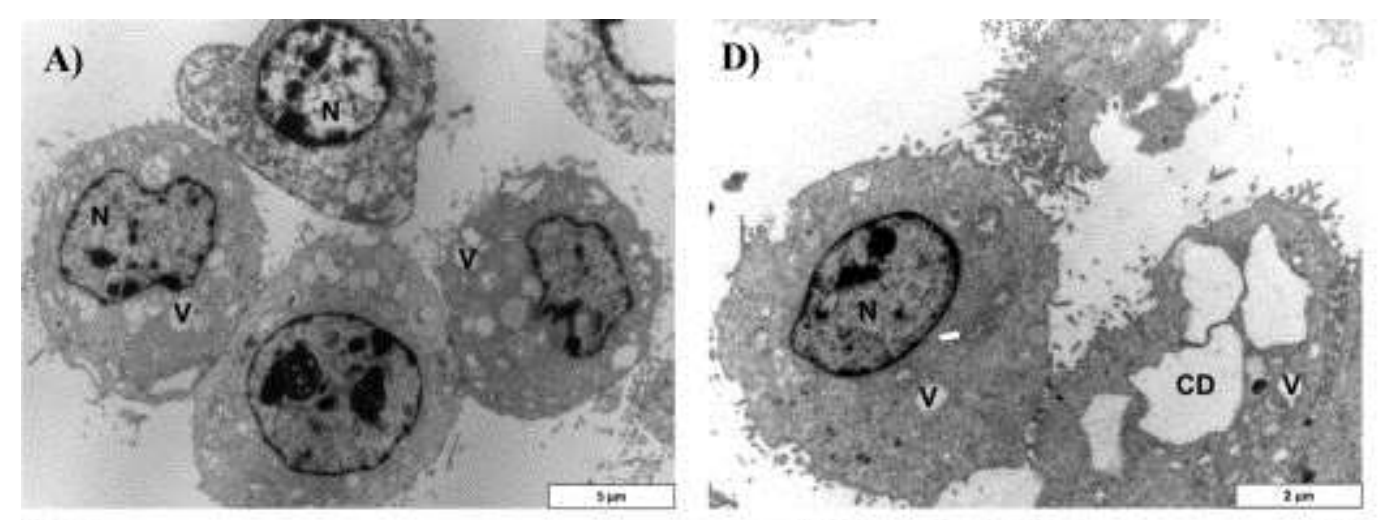

24h
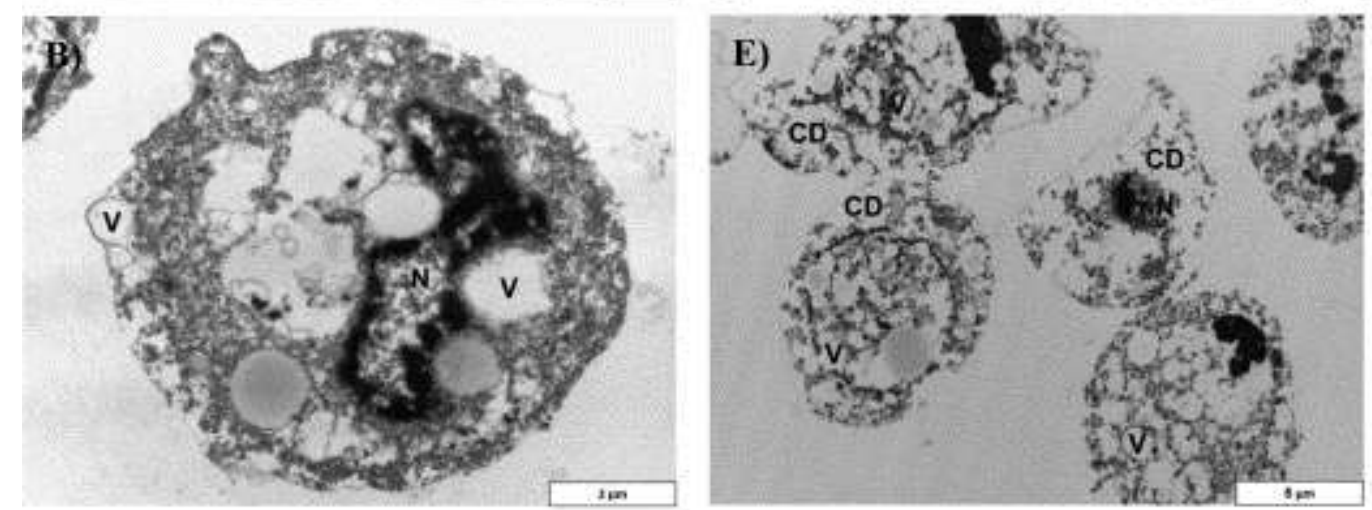

$48 \mathrm{~h}$
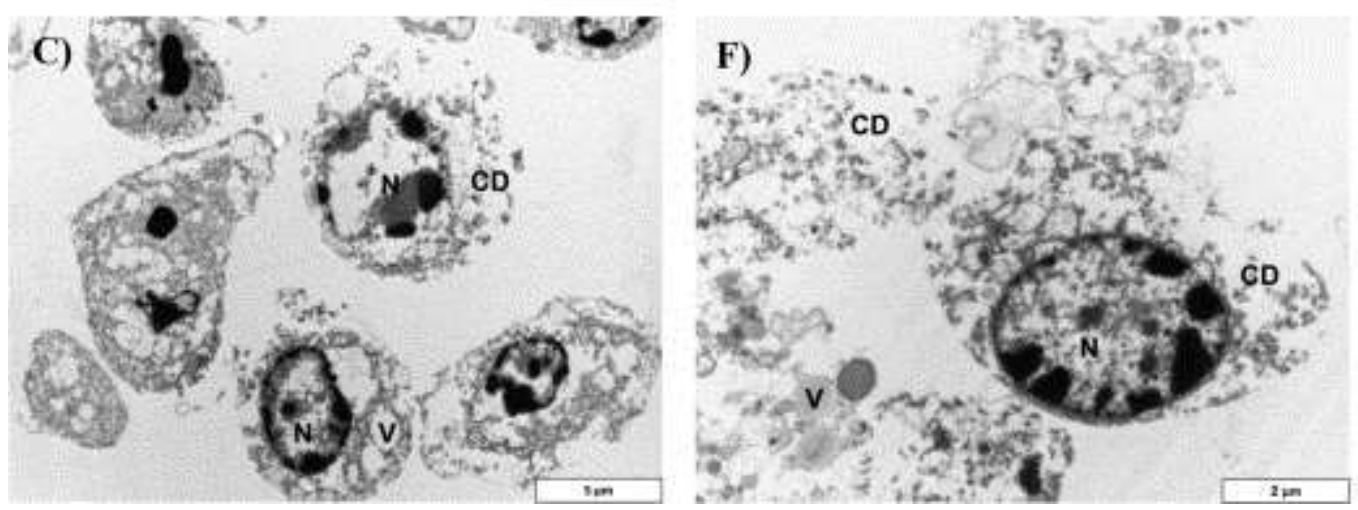

$72 \mathrm{~h}$

Fig. 7. Electron micrographs showing MDBK cells exposed to $750 \mu \mathrm{M}$ of diplodiatoxin (A, B, C) and dipmatol (D, E, F) for 24, 48 and $72 \mathrm{~h}$. $\mathrm{N}$ = nucleus; $\mathrm{V}=$ vacuoles; $\mathrm{CD}=$ cytoplasmic disruption; arrows = mitochondria.

The subcellular changes observed in MDBK cells following treatment with diplodiatoxin and dipmatol for 24, 48 and $72 \mathrm{~h}$ are shown in Fig. 7. The MDBK cells exposed for $24 \mathrm{~h}$ to diplodiatoxin contained numerous swollen mitochondria and most of these mitochondria had progressed to form electron-lucent vacuoles (Fig. 7A) when compared with the control MDBK cells (Fig. S3A). Some of the MDBK cells exhibited abnormal nuclei with fragmented nuclear matrix and chromatin condensation. At this stage, both the nuclear and plasma membranes appeared to be intact. The subcellular damage seemed to be progressive and at $48 \mathrm{~h}$ of exposure of MDBK cells to diplodiatoxin, the number and size of the electronlucent vacuoles increased and protrusion of the cytoplasm was also observed (Fig. 7B). There was complete disappearance of the mitochondria in comparison with the control MDBK cells (Fig. S3B). Changes in the nuclear morphology were more evident and included invagination of the nuclear membrane and increased chromatin condensation which were similar to those observed in the necrotic MDBK cells (Fig. S3H). The plasma membrane appeared to be intact at $48 \mathrm{~h}$ of exposure. After $72 \mathrm{~h}$, the electron-lucent cytoplasmic vacuoles progressed to complete disruption of the cytoplasm (Fig. 7C). Disruption in some parts of the plasma 
membrane, similar to that observed in the necrotic MDBK cells (Fig. S3I), was also noticed in most of the cells.

The MDBK cultures treated with dipmatol for $24 \mathrm{~h}$ contained several swollen mitochondria and electron-lucent cytoplasmic vacuoles (Fig. 7D) when compared with the control MDBK cells (Fig. S3A). Some of the MDBK cells had normal nuclei with intact membranes as well as intact plasma membranes. Distinct changes were visible at $48 \mathrm{~h}$ of exposure to dipmatol and included the complete disappearance of mitochondria, nuclear fragmentation accompanied by chromatin condensation and increase in the presence of electron-lucent vacuoles in the cytoplasm (Fig. 7E) (subcellular changes consistent with the necrotic cells, Fig. S3E and SH). Complete disruption of the cells, together with the loss of plasma membranes as well as nuclear fragmentation, were evident after $72 \mathrm{~h}$ of exposure to dipmatol and these subcellular changes were similar to those observed in the necrotic MDBK cells (Fig. S3H and SI).

\section{Discussion}

The availability of purified metabolites from $S$. maydis-contaminated cultures has made it possible to investigate the cytotoxicity of these mycotoxins in vitro. Previously, in vivo models were used to investigate the toxicity of the three $S$. maydis metabolites i.e. diplodiatoxin, dipmatol and diplonine ( Ackerman et al., 1995, Rao et al., 2003, Snyman et al., 2011 and Steyn et al., 1972). In rats, diplodiatoxin was reported to cause liver damage (i.e. increased alkaline and acid phosphatase, as well as aspartate and alanine aminotransferase activities) and inhibition of the brain acetylcholinesterase activity (Rao et al., 2003). There is a dearth of information on the in vivo toxicity of dipmatol and diplonine, except that the toxicity of dipmatol was evaluated in broiler chickens ( Ackerman et al., 1995) and guinea pigs dosed with diplonine (1580 $\mathrm{mg} / \mathrm{kg}$ body weight) exhibited clinical signs akin to the neurological signs observed in ruminants suffering from diplodiosis (Snyman et al., 2011). Hence, the mechanism of action of the currently known S. maydis metabolites is poorly understood. For the first time, we have characterized the cell death caused by diplodiatoxin and dipmatol, and found that diplodiatoxin and dipmatol at high concentrations $(750 \mu \mathrm{M})$ induced necrosis and caspases-dependent apoptosis. In addition, the two mycotoxins caused mitochondrial damage, cytoplasmic vacuolation and nuclear fragmentation in Neuro-2a, CHO-K1 and MDBK cells.

In another study, using the xCELLigence and methyl-thiazol-tetrazolium (MTT) assays, diplodiatoxin and dipmatol induced a concentration-dependent cytotoxic response in Neuro$2 \mathrm{a}, \mathrm{CHO}-\mathrm{K} 1$ and MDBK cells at the concentration range of 10-750 $\mu \mathrm{M}$ (Masango et al., 2014). In the current study, the roles that necrosis and/or apoptosis play in the cytotoxicity observed in the three cell lines exposed to diplodiatoxin and dipmatol was investigated further. Initially, the effects of the $S$. maydis metabolites on the plasma membranes of the three cell lines was studied using the LDH and PI flow cytometry assays. Exposure of Neuro2a, CHO-K1 and MDBK cells to $750 \mu \mathrm{M}$ of diplodiatoxin and dipmatol affected the plasma membrane integrity of the cells. Monitoring of plasma membrane integrity is most commonly used as an indicator of cell viability since the plasma membrane is essential in cell functioning ( Niemenin et al., 1992). As a result, the inability of cells to retain cytoplasmic enzymes, such as LDH, as well as the failure to exclude certain dyes, such as PI, from entering the cells reflects irreversible plasma membrane damage and is generally accepted as an indicator of the necrotic cell death pathway (Korzeniewski and Callewaert, 1983). Additionally, a significant positive linear correlation $(r=0.45256 ; P<0.0001)$ was detected 
between LDH and PI flow cytometry assays used in the current study. Other studies have also reported a linear correlation between the LDH release and PI uptake in Madin-Darby canine kidney (MDCK) cells exposed to mercuric chloride $\left(\mathrm{HgCl}_{2}\right)$ (Gores et al., 1988) and in hepatocytes exposed to cadmium (Cd) (Koizumi et al., 1996). The extent of membrane damage was reported by Liao et al. (2011) to be related to variations in membrane components (i.e. membrane protein and phospholipids) of the different cell types.

Subsequently, apoptosis was evaluated in the Neuro-2a, CHO-K1 and MDBK cell lines treated with the two $S$. maydis toxic metabolites using the caspase-3/7 and Annexin V-FITC flow cytometry assays. The results obtained indicated that exposure of the three cell lines to $750 \mu \mathrm{M}$ concentrations of diplodiatoxin and dipmatol induced apoptosis. In addition, a significant positive linear correlation $(r=0.85850 ; P<0.0001)$ was detected between the two assays. The involvement of caspase-3/7 enzymes in apoptosis was previously reported for cultured human melanoma cells exposed to staurosporine (Zhang et al., 2004) and human monocytic leukemia (U937) cells treated with T-2 toxin (Huang et al., 2007). The apoptosis induced in this study was caspase-dependent as demonstrated by the activation of caspase-3/7 enzymes following exposure of the three cell lines to diplodiatoxin and dipmatol at high concentrations. In their study, Du et al. (2012) reported an increased expression of caspase-3 and -9 enzymes after treatment of human hepatocellular carcinoma (HepG2) cells with trichothecenes. An increase in caspase activity was also reported with staurosporine-induced apoptosis in CHO-K1 cells (Zhang et al., 1998). On the other hand, apoptosis has also been suggested to occur via caspase-independent mechanisms (Zhang et al., 2004). A number of studies confirmed Annexin V-FITC flow cytometry to be a useful tool in detecting cells undergoing apoptosis. Annexin V-FITC was used successfully in detecting apoptosis in cultured HepG2 cells exposed to T-2 toxin (Du et al., 2012) and tacrine (Gao et al., 2014), and these studies have also demonstrated a positive correlation between the caspase-3/7 and Annexin V-FITC flow cytometry assays.

Results presented in this study concur with previous studies reporting on the induction of both apoptosis and necrosis following exposure of cells to toxins (Denecker et al., 2001; Gao et al., 2014; Sawai and Domae, 2011). Gao et al. (2014) reported that both necrosis and apoptosis contributed to the tacrine-induced death of HepG2 cells, but concluded that tacrineinduced apoptosis was the main cause. Denecker et al. (2001) demonstrated that in murine fibrosarcoma (L929sA) cells treated with tumour necrosis factor (TNF), the release of active caspases into the culture supernatant coincided with the release of LDH. Dual staining (i.e. Annexin-V positive/PI positive) of both apoptotic and primary necrotic U937 cells treated with TNF was reported by Sawai and Domae (2011).

Finally, TEM was used to compare the cell death pathways observed in this study with their typical morphologies. Necrotic cells typically show cytoplasmic vacuolation, swelling of mitochondria, rupture of both nuclear and plasma membranes and appear as faintly stained cells with nuclear ghosts (Vermes et al., 1995). By contrast, apoptotic cells show chromatin condensation, nuclear fragmentation and formation of apoptotic bodies. The cell membrane of apoptotic cells remains intact, although it may often show some blebbing (Loos and Engelbrecht, 2009). Mitochondrial damage, cytoplasmic vacuolation and nuclear fragmentation were the major subcellular changes induced by diplodiatoxin and dipmatol in this study. One of the first in vitro changes observed included morphological alterations to the mitochondria. Mitochondria play an important role in oxidative phosphorylation ( Green and Reed, 1998), maintenance of intracellular calcium ion concentrations (Kroemer and 
Reed, 2000) and facilitation of apoptotic and necrotic cell death pathways (Kroemer et al., 1998).

The second major subcellular change observed in this study was the progression of mitochondrial damage to cytoplasmic vacuole formation with prolonged exposure to diplodiatoxin and dipmatol. This progression has been reported previously for other toxins (Carranza-Rosales et al., 2005 and Pollanen et al., 1990). In most cases, vacuolation occurs after a detrimental stimulus and leads to an increase in size and number of vacuoles in the cytoplasm. Up to a certain threshold, vacuolation is fully reversible and cells can recover to full functionality. However, beyond this threshold, the process of vacuolation is irreversible and the structural damage caused leads to cell death (Henics and Wheatley, 1999).

Nuclear fragmentation accompanied by chromatin condensation was the third major subcellular change observed in this study. Caspases, especially caspase- 3 and -7 enzymes, are responsible for cleaving various substrates involved in regulation of nuclear changes during apoptosis (Robertson et al., 2000). Caspase-3 enzyme is capable of cleaving poly-(ADPribose) polymerase (PARP), DNA-dependent protein kinase (DNA-PK) and lamin, which are protein substrates responsible for maintaining the genomic integrity. The PARP and DNA-PK proteins have also been implicated in cellular DNA repair processes (Nagata, 2000).

Chromatin condensation was reported to occur as a result of the loss of structural integrity of the nuclear matrix (Susin et al., 2000). It could be interesting in future studies to verify whether the lesions observed in the current study are comparable with lesions induced by the purified mycotoxins in animals and to also verify the role of mitochondria, if any, in the development of the disease in vivo.

The high concentration $(750 \mu \mathrm{M})$ of $S$. maydis toxins that induced cell death in this study could be related to the fact that $S$. maydis cultures caused death only at high doses in vivo. Kellerman et al. (1985) showed that 13 out of 16 cattle that were fed $10-30 \mathrm{~g} / \mathrm{kg} \mathrm{S}$. maydis culture material developed typical signs of diplodiosis, but none died of intoxication. The first signs of the disease were reported by these authors 2-8 days after feeding ( Kellerman et al., 1985). Day-old ducklings and adult rats given an average dose of $21 \mathrm{~g}$ of $S$. maydis cultures died 5 days after dosing ( Rabie et al., 1985). These results indicate the possibility of metabolic activation of the $S$. maydis toxins in in vivo systems prior to manifestation of the signs of diplodiosis. Since the $S$. maydis culture material contain the combination of various S. maydis toxins, synergism between the different toxins is also possible in in vivo systems.

\section{Conclusion}

In summary, the results presented in this study show that the death observed in the Neuro-2a, $\mathrm{CHO}-\mathrm{K} 1$ and MDBK cells after exposure to high concentrations $(750 \mu \mathrm{M})$ of diplodiatoxin and dipmatol was due to necrosis and caspase-dependent apoptosis. Furthermore, the subcellular changes observed in the three cell lines after exposure to the two $S$. maydis metabolites support the results obtained with the necrotic and apoptotic assays. Our findings have laid a foundation for further studies aimed at solving the challenge of diplodiosis. Future studies should investigate in detail how the cell death is occurring and which macromolecules are being targeted during the cell death processes.

\section{Conflict of interest}

The authors declare that there are no conflicts of interest. 


\section{Ethical statement}

The authors declare that this study was funded by the National Research Foundation (NRF), International Foundation for Science (IFS) and the Joy Liebenberg Trust Fund. No sentient animals were used in the current study.

\section{Acknowledgements}

This work was supported by the International Foundation for Science (IFS), Stockholm, Sweden, through a grant to MG Masango (Grantee Number: B/5114-1), the National Research Foundation (NRF) and the Joy Liebenberg Trust Fund (Grantee Number: MasangoJT). The authors would like to thank Dr Louis Ackerman (University of Pretoria) for the diplodiatoxin and dipmatol, Ms Nicolene Thiebaut (ARC-Biometry Unit) for the statistical analysis and Dr Mirinda Van Kleef (ARC-OVI) for her assistance with the flow cytometry analysis. We are also grateful to Ms Erna Van Wilpe and Dr Lizette Du Plessis (University of Pretoria) for preparation of the TEM samples.

\section{References}

Ackerman, L.G.J., Combrink, S., Horak, R.M., Kuhn, M., Learmonth, R.L., Lubben, A., Maharaj, V.J., Rabie, C.J., 1995. A novel hydroxylated fatty acid isolated from cultures of Diplodia maydis on maize. In: Book of Abstract e Poster B1, 5th Frank Warren National Organic Chemistry Conference. Aventura Aldam, Free State, South Africa.

Carranza-Rosales, P., Said-Fern andez, S., Sepúlveda-Saavedra, J., Cruz-Vega, D.E., Gandolfi, A.J., 2005. Morphologic and functional alterations induced by low doses of mercuric chloride in kidney OK cell line: ultrastructural evidence for an apoptotic mechanism of damage. Toxicol. 210, 111-121.

Darvall, P.M., 1964. Mouldy corn cobs, a danger to cows. Qld. Agric. J. 90, 692-693.

Denecker, G., Vercammen, D., Steemans, M., Vanden Berghe, T., Brouckaert, G., Loo, G., Zhivotovsky, B., Fiers, W., Grooten, J., Declercq, W., Vandenabeele, P., 2001. Death receptor-induced apoptotic and necrotic cell death: differential role of caspases and mitochondria. Cell Death Diff. 8, 829-840.

Department of Agriculture, Forestry and Fisheries (DAFF), 2013. Trends in the Agricultural Sector. http://www.daff.gov.za/docs/statsinfo/Trends13.pdf.

Du, R.H., Cui, J.T., Wang, T., Zhang, A.H., Tan, R.X., 2012. Trichothecin induces apoptosis of HepG2 cells via caspase-9 mediated activation of the mitochondrial death pathway. Toxicon 59, 143-50.

Flett, B.C., McLaren, N.W., 1994. Optimum disease potential for evaluating resistance to Stenocarpella maydis ear rot in corn hybrids. Plant Dis. 78, 587-589.

Freshney, I., 2001. Application of cell cultures to toxicology. Cell Biol. Toxicol. 17, 213-230.

Gao, C., Ding, Y., Zhong, L., Jiang, L., Geng, C., Yao, X., Cao, J., 2014. Tacrine induces apoptosis through lysosome- and mitochondria-dependent pathway in HepG2 cells. Toxicol. In Vitro. 28, 667-674.

Glauert, A.M., 1980. Fixation, dehydration and embedding of biological specimens. In: Glauert, A.M. (Ed.), Practical Methods in Electron Microscopy, vol. 3. Elsevier Biomedical Press, North-Holland, p. 91.

Gores, G.J., Nieminen, A.L., Fleishman, K.E., Dawson, T.L., Herman, B., Lemasters, J.J., 1988. Extracellular acidosis delays onset of cell death in ATP-depleted hepatocytes. Am. J. Physiol. 255, 315-322. 
Green, D.R., Reed, J.C., 1998. Mitochondria and apoptosis. Science 281, 1309e1312. Henics, T., Wheatley, D.N., 1999. Cytoplasmic vacuolation, adaptation and cell death: a view on new perspectives and features. Biol. Cell 91, 485-498.

IHuang, P., Akagawa, K., Yokoyama, Y., Nohara, K., Kano, K., Morimoto, K., 2007. T-2 toxin initially activates caspase-2 and induces apoptosis in U937 cells. Toxicol. Lett. 170, 1-10.

Kellerman, T.S., Rabie, C.J., Van Der Westhuizen, G.C.A., Kriek, N.P.J., Prozesky, L., 1985. Induction of diplodiosis, a neuromycotoxicoses, in domestic ruminants with cultures of indigenous and exotic isolates of Diplodia maydis. Onder-stepoort J. Vet. Res. 52, 35-42.

Koizumi, T., Shirakura, H., Kumagai, H., Tatsumoto, H., Suzuki, K.T., 1996. Mechanism of cadmium-induced cytotoxicity in rat hepatocytes: cadmium-induced active oxygen-related permeability changes of the plasma membrane. Toxicol. 114, 125-134.

Korzeniewski, C., Callewaert, D.M., 1983. An enzyme-release assay for natural cytotoxicity. J. Immunol. Methods 64, 313-320.

Kroemer, G., Dallaporta, B., Resche-Regon, M., 1998. The mitochondrial death/life regulator in apoptosis and necrosis. Annu. Rev. Physiol. 60, 619-642.

Liao, T.T., Jia, R.W., Shi, Y.L., Jia, J.W., Wang, L., Chua, H., 2011. Propidium iodide staining method for testing the cytotoxicity of 2,4,6-trichlorophenol and per-fluorooctane sulfonate at low concentrations with Vero cells. J. Environ. Sci. Health., Part A 46, 1769-1775.

Loos, B., Engelbrecht, A.-M., 2009. Cell death. A dynamic response concept. Autophagy 5, 1-14.

Marasas, W.F.O., Gelderblom, W.C.A., Shephard, G.S., Vismer, H.F., 2012. Mycotoxicological research in South Africa 1910-2011. World Mycotoxin J. 5, 89e102. Masango, M.G., Flett, B.C., Ellis, C.E., Botha, C.J., 2015. Stenocarpella maydis and its toxic metabolites: a South African perspective on diplodiosis. World Mycotoxin J. 8, 341-350.

Masango, M.G., Ferreiara, G.C.H., Ellis, C.E., Elgorashi, E.E., Botha, C.J., 2014. Cytotoxicity of diplodiatoxin, dipmatol and diplonine, metabolites synthesized by Stenocarpella maydis. Toxicon 82, 26-29.

Nagata, S., 2000. Apoptotic DNA fragmentation. Exp. Cell. Res. 256, 12-18.

Nieminen, A.L., Gores, G.J., Bond, J.M., Imberti, R., Herman, B., Lemasters, J.J., 1992. A novel cytotoxicity screening assay using a multiwell fluorescence scanner. Toxicol. Appl. Pharmacol. 115, 147-155.

Odriozola, E., Ode on, A., Canton, G., Clemente, G., Escand e, A., 2005. Diplodia maydis: a cause of death of cattle in Argentina. N. Z. Vet. J. 53, 160-161.

Pollanen, M.S., Quinn, B.A., Wollenberg, G.K., Hayes, M.A., 1990. Reversible mitochondrial swelling in cultured rat hepatocytes exposed to 1,2-dimethylhydrazine. Exp. Mol. Pathol. 52, 170-178.

Rabie, C.J., Kellerman, T.S., Kriek, N.P.J., Van Der Westhuizen, G.C.A., De Wet, P.J., 1985. Toxicity of Diplodia maydis in farm and laboratory animas. Food Chem. Toxicol. 23, 349-353.

Rao, S.K., Achar, P.N., Rahman, M.F., 2003. Biochemical changes in liver and serum of diplodiatoxin (Stenocarpella maydis) treated male and female rats. Drug Chem.Toxicol. 26, 231-243.

Riet-Correa, F., Rivero, R., Odriozola, E., Adrien, M.D., Medeiros, R.M.T., Schild, A.L., 2013. Mycotoxicoses of ruminants and horses. J. Vet. Diagn. Invest 25, 692-708. 
Robertson, J.D., Orrenius, S., Zhivotovsky, B., 2000. Review: nuclear events in apoptosis. J. Struct. Biol. 129, 346-358.

Rogers, K.D., Cannistra, J.C., Gloer, J.B., Wicklow, D.T., 2014. Diplodiatoxin, chaetoglobosins and diplonine associated with a field outbreak of Stenocarpella ear rot in Illinois. Mycotoxin Res. 30, 61-70.

Sawai, H., Domae, N., 2011. Discrimination between necrosis and apoptosis by necrostatin-1 in annexin Vpositive/propidium iodide-negative cells. Biochem.. Biophys. Res. Commun. 411, 569-573.

Snyman, L.D., Kellerman, T.S., Vleggaar, R., Flett, B.C., Basson, K.M., Schultz, R.A., 2011. Diplonine, a neurotoxin isolated from cultures of the fungus Stenocarpella maydis (Berk.) Sacc. that induces diplodiosis. J. Agric. Food Chem. 59, 9039-9044.

Steyn, P.S., Wessels, P.L., Holzapfel, C.W., 1972. The isolation of a toxic metabolite from Diplodia maydis (BERK.) SACC. Tetrahedron 28, 4775-4785.

Susin, S.A., Daugas, E., Ravagnan, L., Samejima, K., Zamzami, N., Loeffler, M., Costantini, P., Ferri, K.F., Irinopoulou, T., Pr evost, M.-C., Brothers, G., Mak, T.W., Penninger, J., Earnshaw, W.C., Kroemer, G., 2000. Two distinct pathways leading to nuclear apoptosis. J. Exp. Med. 192, 571-579.

Van der Bijl, P.A., 1914. Preliminary investigation on the deterioration of maize infected with Diplodia zeae (Schw.) Lev. Trans. R. Soc. S. Afr. 4, 231-239.

Vermes, I., Haanen, C., Steffens-Nakken, H., Reutelingdperger, C., 1995. A novel assay for apoptosis flow cytometric detection of phosphatidylserine expression on early apoptotic cells using fluorescein labelled annexin V. J. Immunol. Methods 184, 39-51.

Weyermann, J., Lochmann, D., Zimmer, A., 2005. A practical note on the use of cytotoxicity assays. Int. J. Pharm. 288, 369-376.

Zhang, G., Yan, G., Gurtu, V., Spencer, C., Kain, S.R., 1998. Caspase inhibition prevents staurosporine-induced apoptosis in CHO-K1 cells. Apoptosis 3, 27-33.

Zhang, X.D., Gillespie, S.K., Hersey, P., 2004. Staurosporine induces apoptosis of melanoma by both caspasedependent and -independent apoptotic pathways. Mol. Cancer Ther. 3, 187-197. 

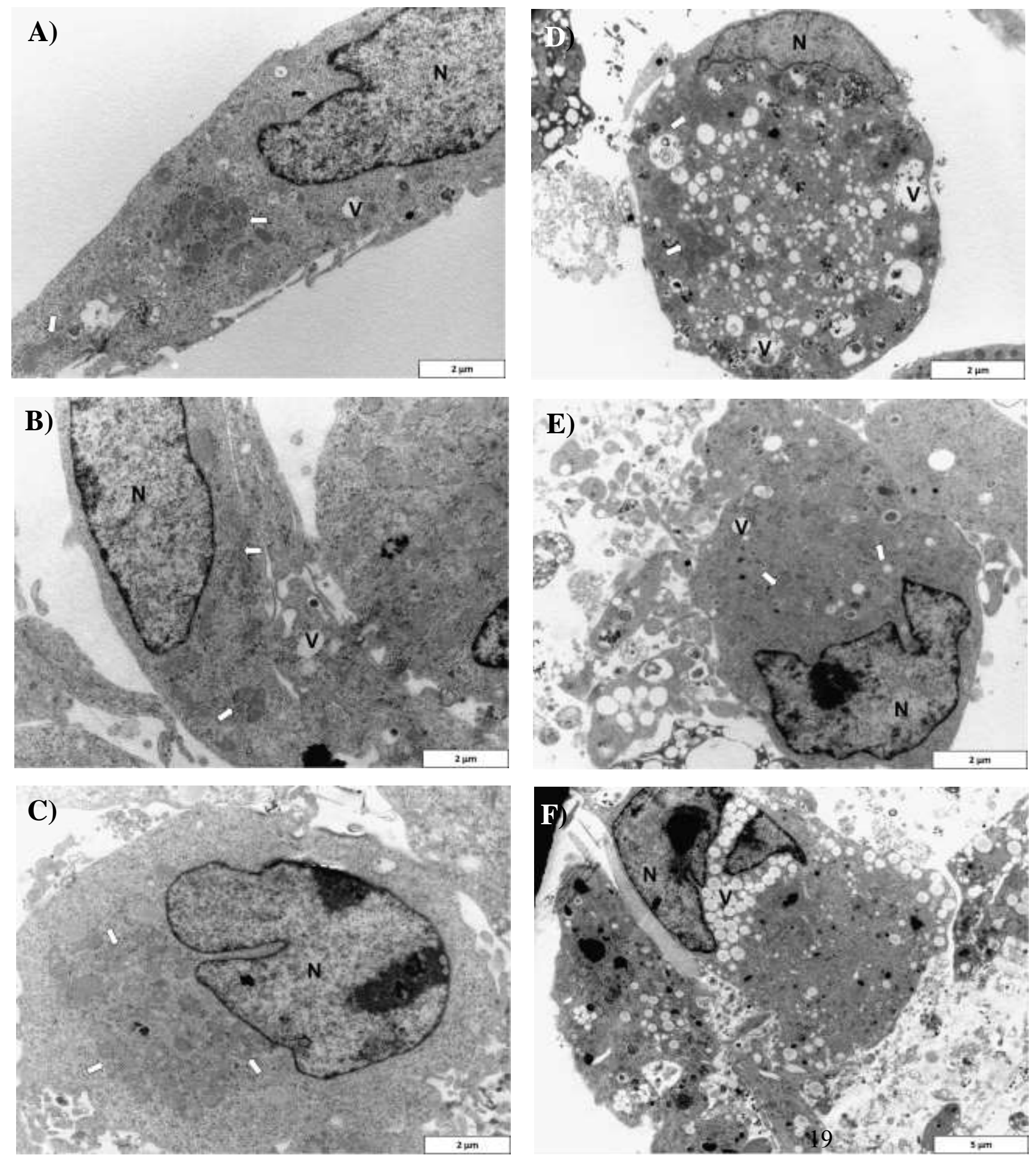
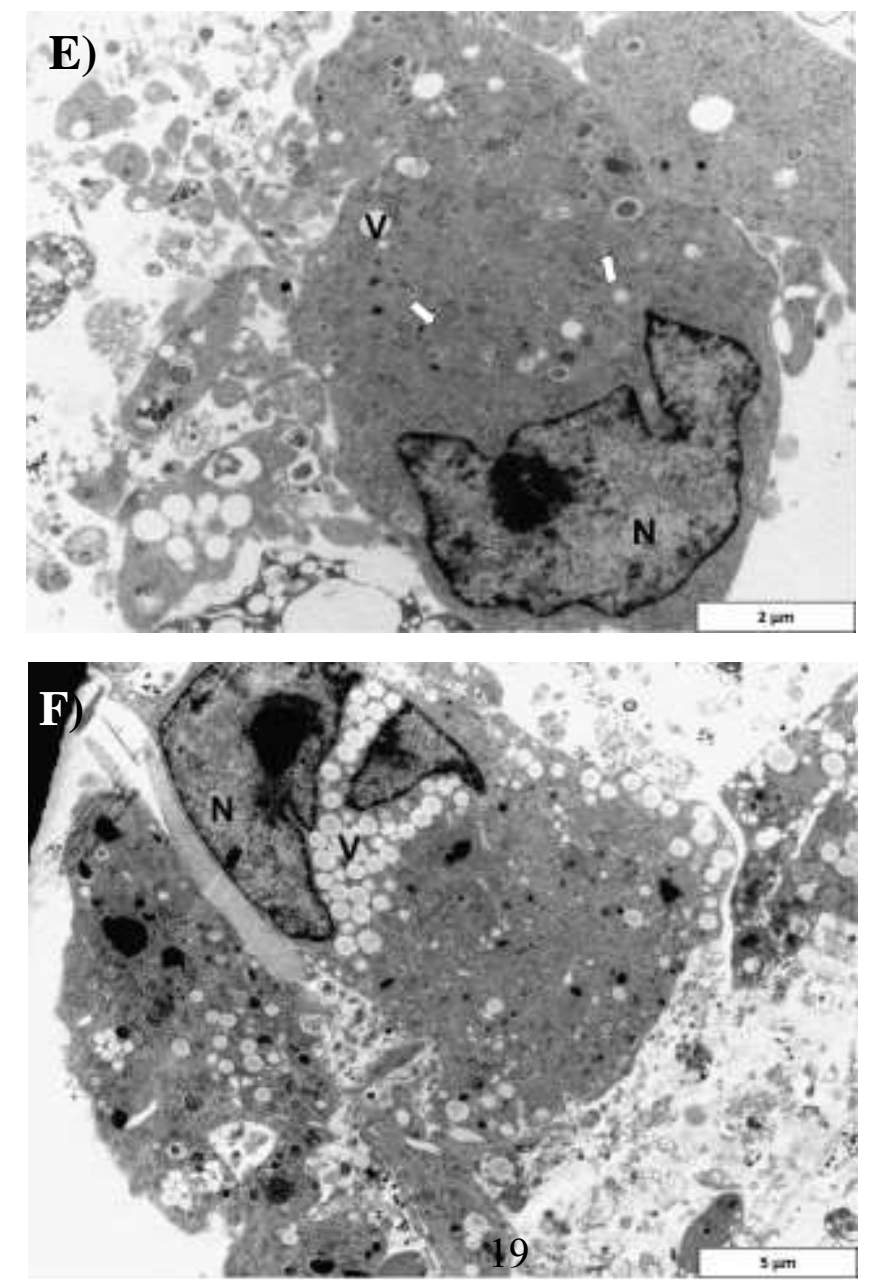

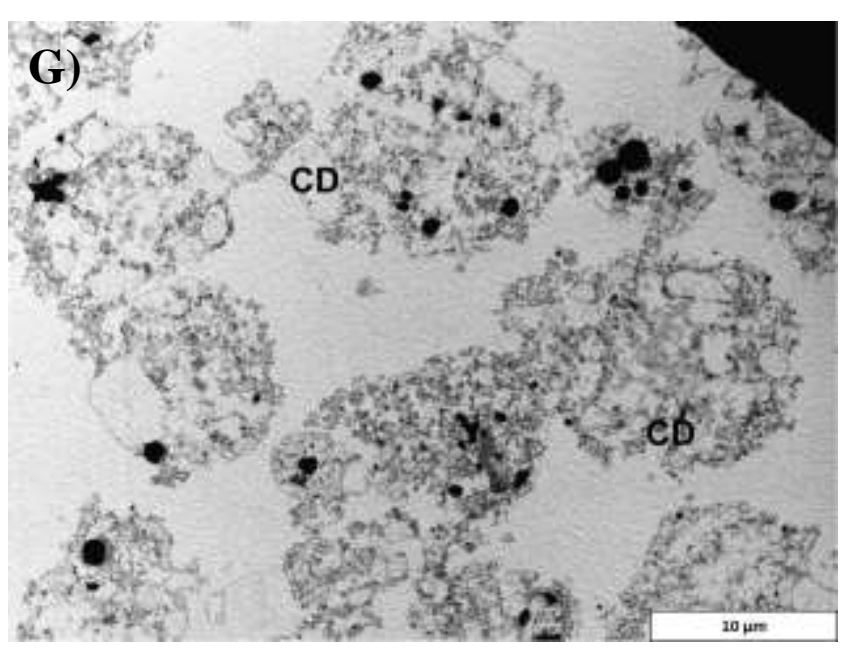

H) river.

$10 \%$ ong

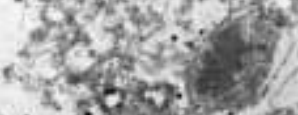
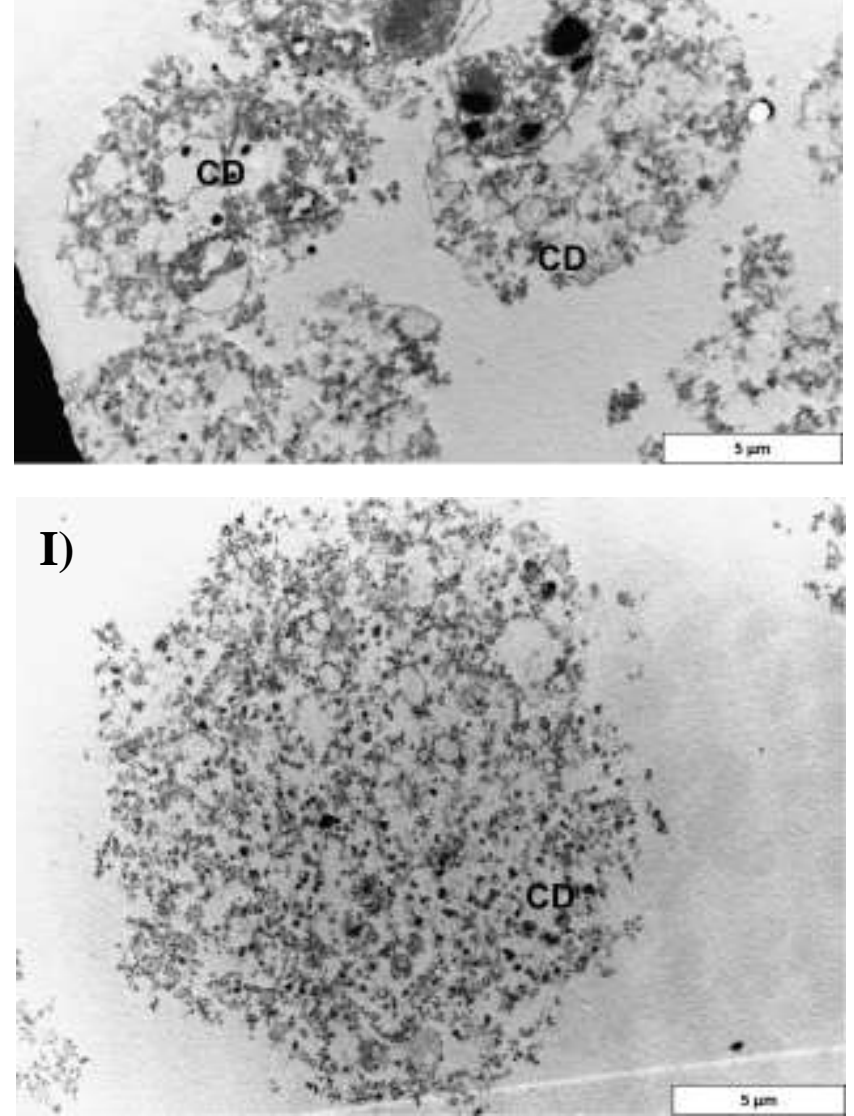
Figure S1. Electron micrographs showing Neuro-2a cells exposed to media (A, B, C), $1 \mu \mathrm{M}$ staurosporine (D, E, F) and 0.01\% Triton-X (G, H, I) for 24, 48 and $72 \mathrm{~h}$. $\mathrm{N}=$ nucleus; $\mathrm{V}=$ vacuoles; $\mathrm{CD}=$ cytoplasmic disruption; arrows = mitochondria; asterisk = chromatin condensation. 

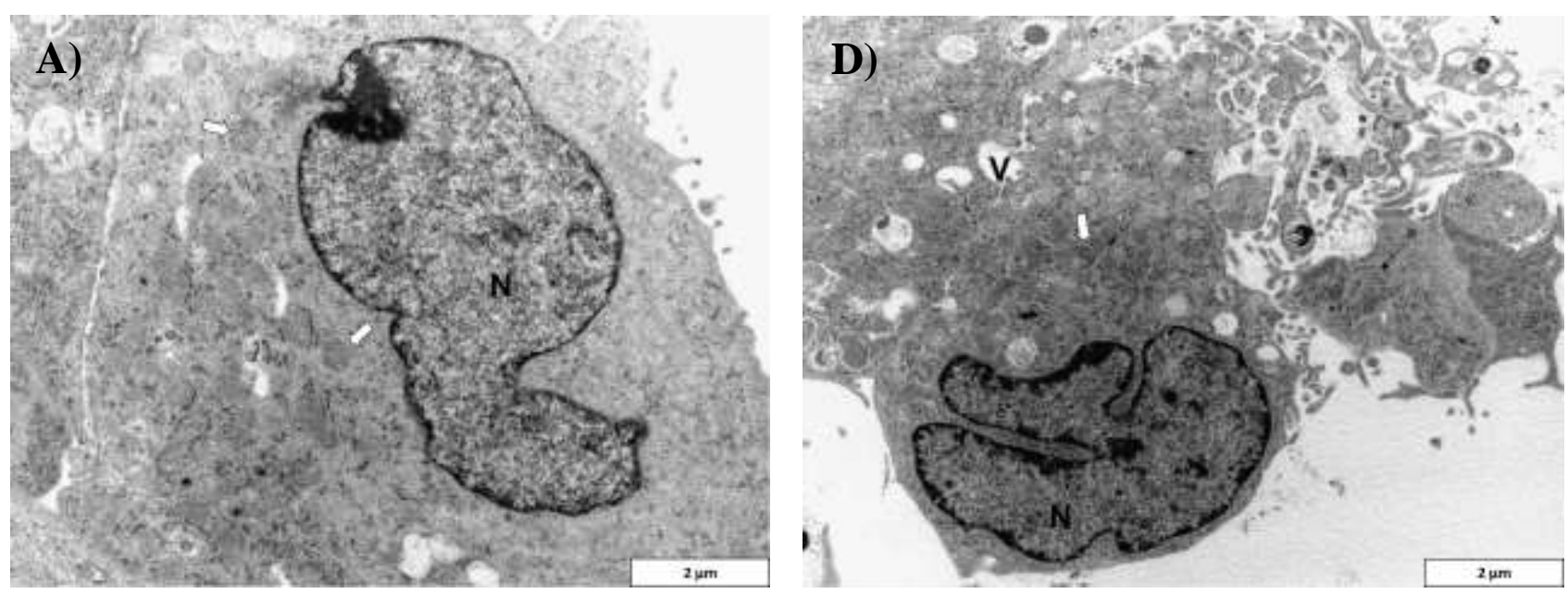

B)
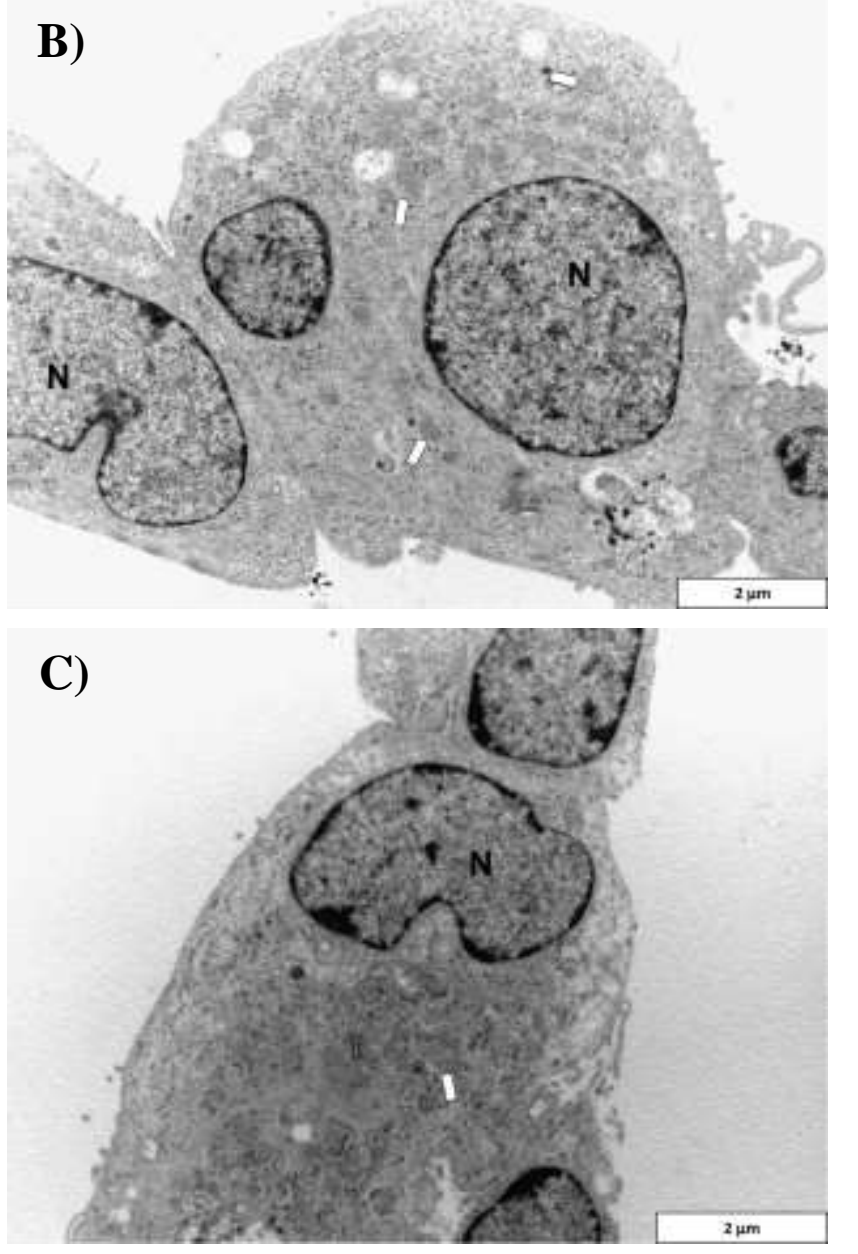

E)
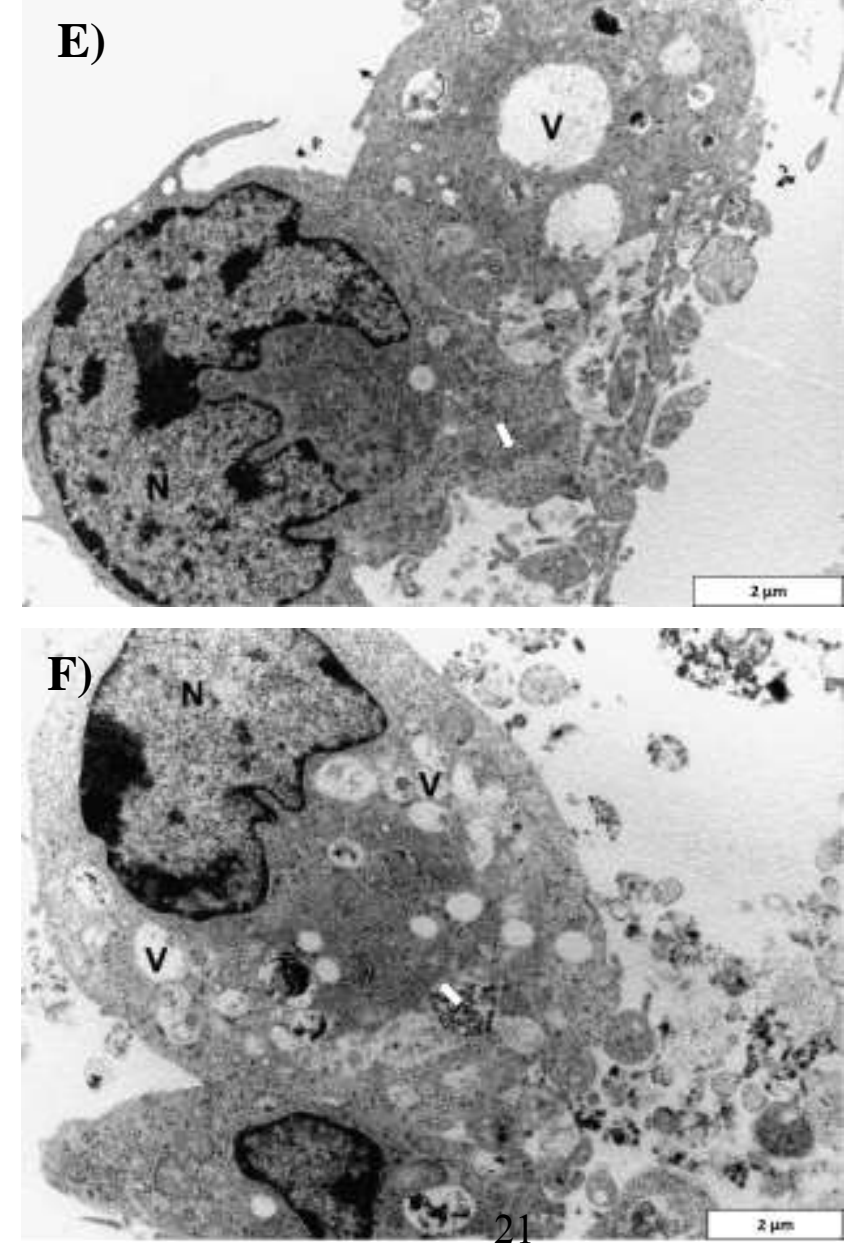

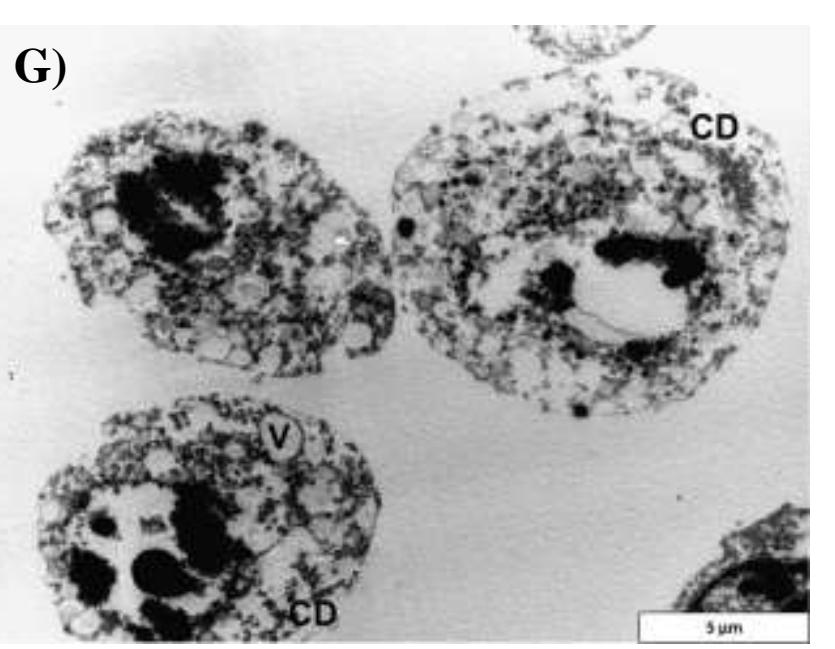

24h
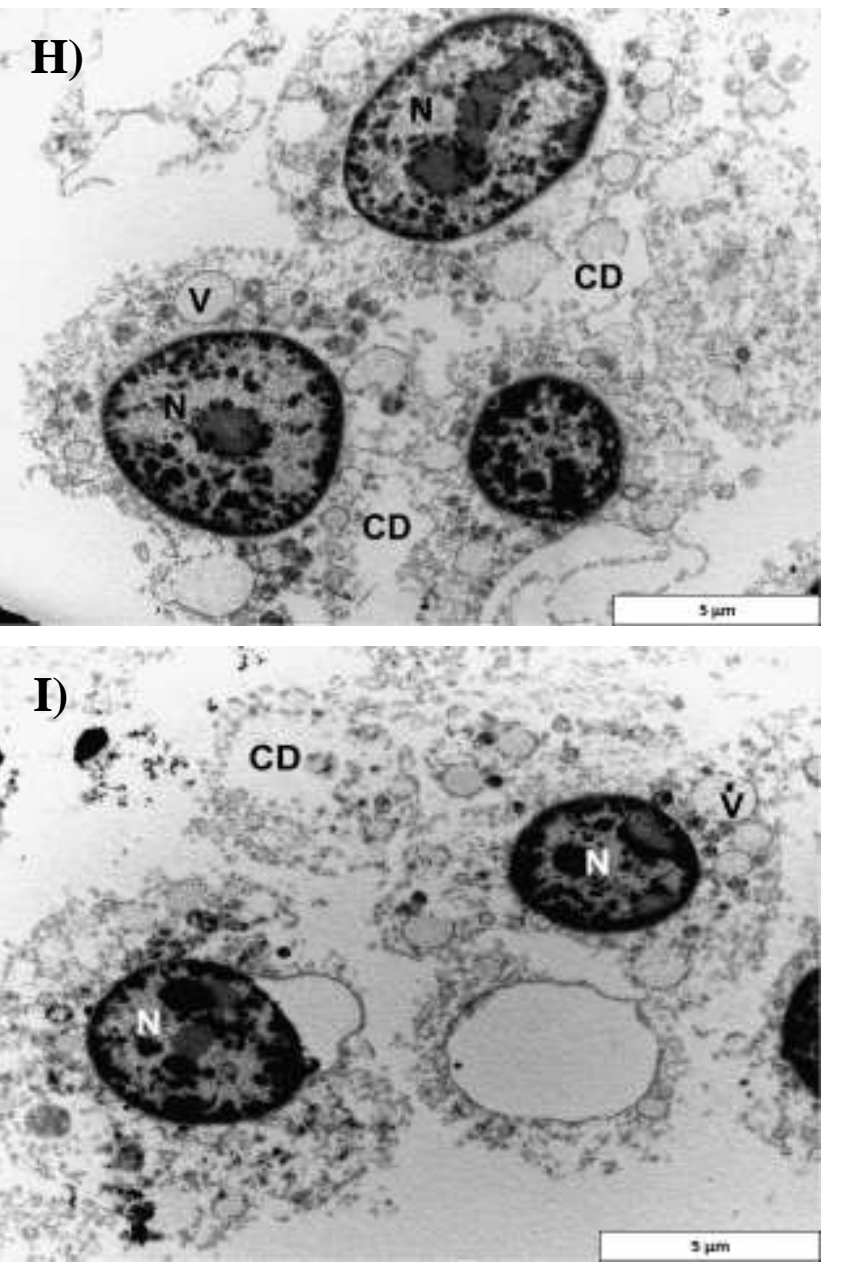

$48 h$

72h 
Figure S2. Electron micrographs showing CHO-K1 cells exposed to media (A, B, C), $1 \mu \mathrm{M}$ staurosporine (D, E, F) and 0.01\% Triton-X (G, H, I) for 24, 48 and $72 \mathrm{~h}$. $\mathrm{N}=$ nucleus; $\mathrm{V}=$ vacuoles; $\mathrm{CD}$ = cytoplasmic disruption; arrows = mitochondria. 

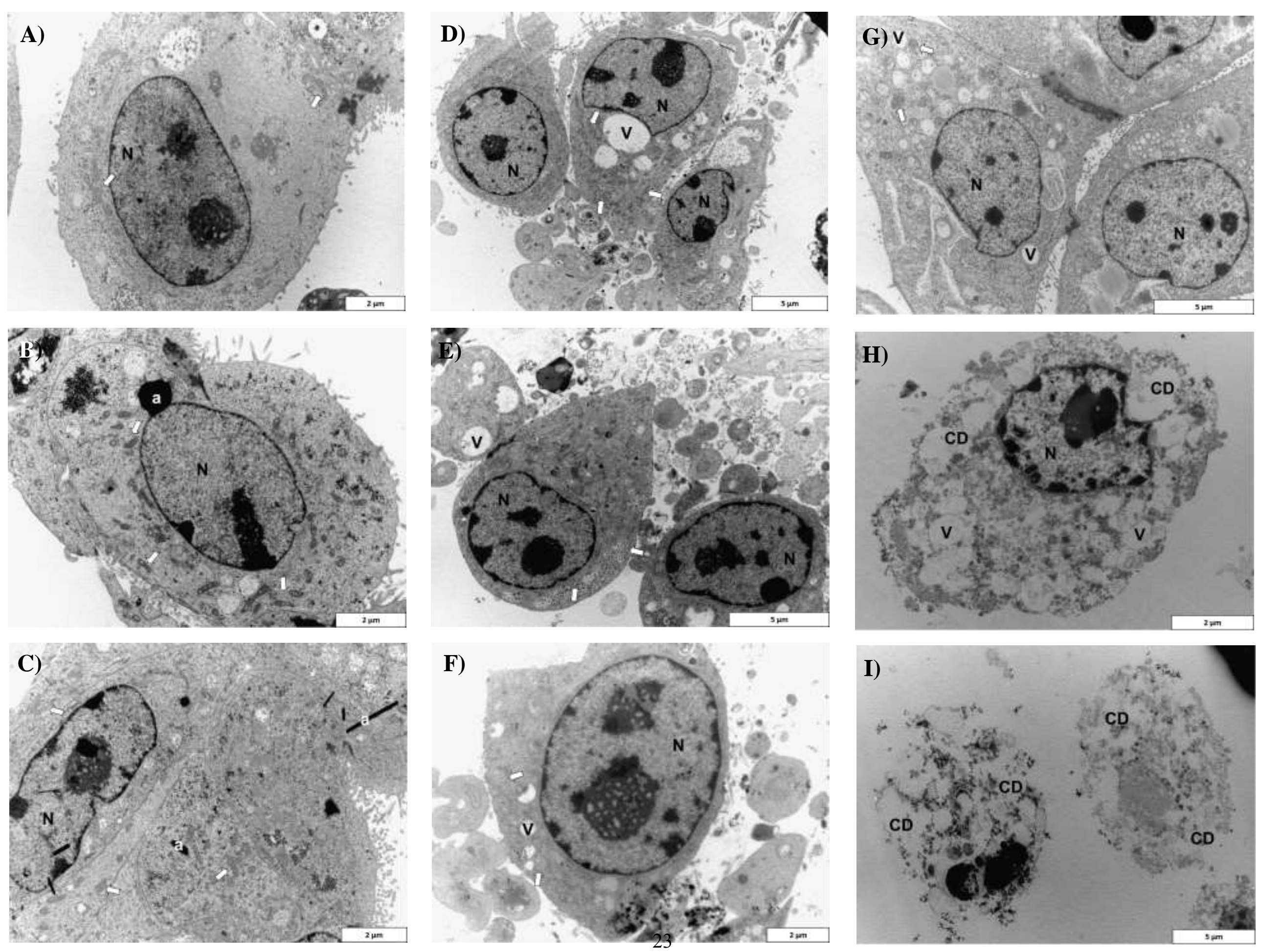

72h 
Figure S3. Electron micrographs showing MDBK cells exposed to media (A, B, C), $1 \mu \mathrm{M}$ staurosporine (D, E, F) and 0.01\% Triton-X (G, H, I) for 24, 48 and $72 \mathrm{~h}$. $\mathrm{N}=$ nucleus; $\mathrm{V}=$ vacuoles; $\mathrm{CD}=$ cytoplasmic disruption; arrows = mitochondria; asterisk = chromatin condensation; $\mathrm{a}=$ staining artefact. 